\title{
Intracellular Bacterial Symbionts in Corals: Challenges and Future Directions
}

\author{
Justin Maire ${ }^{1, * \mathbb{D}}$, Linda L. Blackall ${ }^{1}$ and Madeleine J. H. van Oppen ${ }^{1,2}$ (D) \\ 1 School of Biosciences, The University of Melbourne, Melbourne, VIC 3010, Australia; \\ linda.blackall@unimelb.edu.au (L.L.B.); madeleine.van@unimelb.edu.au (M.J.H.v.O.) \\ 2 Australian Institute of Marine Science, Townsville, QLD 4810, Australia \\ * Correspondence: justin.maire@unimelb.edu.au
}

Citation: Maire, J.; Blackall, L.L.; van Oppen, M.J.H. Intracellular Bacterial Symbionts in Corals: Challenges and Future Directions. Microorganisms 2021, 9, 2209. https://doi.org/ 10.3390/microorganisms 9112209

Academic Editor: Simon K. Davy

Received: 17 September 2021

Accepted: 21 October 2021

Published: 23 October 2021

Publisher's Note: MDPI stays neutral with regard to jurisdictional claims in published maps and institutional affiliations.

Copyright: (c) 2021 by the authors. Licensee MDPI, Basel, Switzerland. This article is an open access article distributed under the terms and conditions of the Creative Commons Attribution (CC BY) license (https:/ / creativecommons.org/licenses/by/ $4.0 /)$.

\begin{abstract}
Corals are the main primary producers of coral reefs and build the three-dimensional reef structure that provides habitat to more than $25 \%$ of all marine eukaryotes. They harbor a complex consortium of microorganisms, including bacteria, archaea, fungi, viruses, and protists, which they rely on for their survival. The symbiosis between corals and bacteria is poorly studied, and their symbiotic relationships with intracellular bacteria are only just beginning to be acknowledged. In this review, we emphasize the importance of characterizing intracellular bacteria associated with corals and explore how successful approaches used to study such microorganisms in other systems could be adapted for research on corals. We propose a framework for the description, identification, and functional characterization of coral-associated intracellular bacterial symbionts. Finally, we highlight the possible value of intracellular bacteria in microbiome manipulation and mitigating coral bleaching.
\end{abstract}

Keywords: symbiosis; coral; intracellular; bacteria

\section{Introduction}

Symbiosis, the association between two or more organisms of distinct species [1,2], is ubiquitous in nature. It includes a diversity of associations ranging from parasitism to mutualism [3-7]. Mutualistic interactions are believed to be among the main evolutionary driving forces, as they generate diversity and accelerate species adaptation via the creation of biological novelty [8-10]. Symbiosis is found in all ecological niches and at different levels of host integration. This includes ectosymbioses (extra-organismal symbioses) and endosymbiosis (intra-organismal symbioses, which can be either extracellular, e.g., in a host cavity or between cells, or intracellular) [11]. Intracellular symbioses are the most intimate forms of symbiosis, often leading to complete inter-dependence between the different partners [12]. It is now widely accepted that eukaryotic organelles, mitochondria and plastids, originated from endosymbiotic integration, highlighting the most extreme level of integration between host and endosymbiont [13].

Intracellular symbiosis between eukaryotes and bacteria is widespread across the tree of life and is known from insects [14,15], marine organisms such as bivalves and tubeworms [16,17], plants [18,19], and protists [20]. The intracellular nature of these associations provides multiple advantages. First, metabolic exchanges are optimized by host-endosymbiont proximity. For example, in the pea aphid Acyrtosiphon pisum, cells harboring the endosymbiont Buchnera aphidicola upregulate the expression of genes involved in the transport of cationic amino acids, the very same amino acids provided by B. aphidicola to its aphid host [21]. Intracellular habitats provide endosymbionts with a stable, nutrientrich environment, although this has historically been hard to demonstrate [22,23]. Second, by sequestering endosymbionts within cells, host immune homeostasis is maintained by preventing unnecessary and potentially harmful immune responses that could be triggered 
by endosymbionts. This was shown in the cereal weevil Sitophilus zeamais: while the endosymbiont Sodalis pierantonius can produce peptidoglycan and can trigger a host immune response [24,25], immune homeostasis is preserved through the high production of host enzymes able to cleave peptidoglycan, thus rendering it non-immunogenic [24]. Finally, population control is also eased in an intracellular context, as was described in symbioses between legume plants and nitrogen-fixing bacteria of the genus Rhizobium. Rhizobium are environmentally acquired by their host and trigger the formation of root nodules in which they are intracellularly housed [18]. Oxygen provision by the plant host is decreased in nodules housing less metabolically efficient strains, leading to lower bacterial density and smaller nodules [26].

Scleractinian corals rely on intracellular photosynthetic dinoflagellates of the Symbiodiniaceae family for their health and survival [27-29], which they house within their gastrodermal cells (Figure 1). In exchange for shelter, inorganic carbon, and other coral metabolic products, Symbiodiniaceae translocate photosynthate directly into the coral cells, thus providing their coral host with an organic carbon source [30,31]. This intracellular photosymbiosis is essential for the survival of scleractinian corals and enables them to build the three-dimensional structures of coral reefs, which are estimated to be home to more than $25 \%$ of the multicellular eukaryotic species in the global oceans [32,33]. While the coral-Symbiodiniaceae symbiosis has survived millions of years and episodes of mass extinctions [29], it has proved fragile in the face of the current climate crisis: the breakdown of this association — coral bleaching — often results in coral starvation, increased chances of opportunistic infection, and eventually death $[34,35]$. Coral bleaching is believed to be caused by excessive production of reactive oxygen species (ROS) by Symbiodiniaceae under thermal and light stress, leading to their death or expulsion from the coral tissues [36-38]. Climate change-related seawater temperature increases have caused a surge in mass coral bleaching events in the past decade and have led to an unprecedented global deterioration of coral reefs [39].

Corals also associate with a multitude of bacteria, which are receiving a rapidly increasing amount of attention [40]. Coral-associated bacteria are thought to be involved in metabolic functions, such as carbon, nitrogen, and sulfur cycling, as well as host protection from pathogens $[40,41]$. Bacteria have been detected in every coral microhabitat, including the mucus [42]; tissue layers [43,44]; gastrovascular cavity [45]; skeleton [46]; and in the case of cyanobacterial pathogens, the mesoglea [47]. However, intracellular coral-associated bacteria, specifically, remain under-studied, with only a handful of reports describing intracellular bacterial symbionts $[43,48-51]$. In this review, we outline the knowledge gaps in the study of intracellular bacterial symbiosis in corals and provide directions to this important field of study by drawing on examples from other animal and plant systems that have been successful in the study of intracellular bacterial symbioses. We also provide examples of applications of intracellular bacteria in the microbiome manipulation field, which is increasingly brought forward as an approach to mitigate coral bleaching [52-54]. 


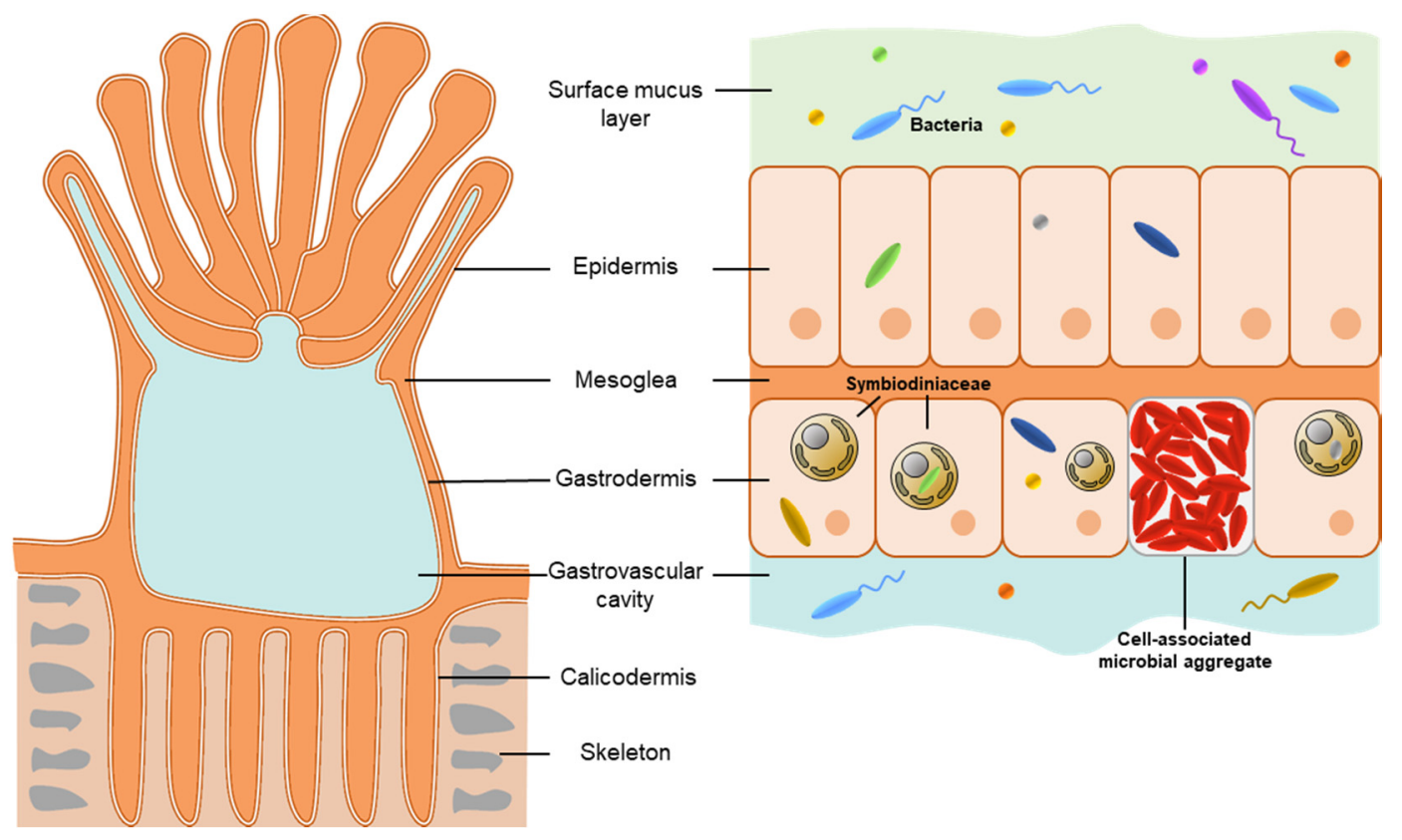

Figure 1. Coral anatomy and microbial associations. A coral colony is composed of many identical polyps (left panel shows an individual polyp), connected by interlaying tissues and sharing a calcium-carbonate skeleton. Each polyp is composed of two cellular layers, the epidermis and the gastrodermis, separated by a largely acellular layer, the mesoglea, although it contains fibroblasts and amoebocytes [55]. The epidermis is covered by the surface mucus layer, where bacteria are highly abundant [42]. Symbiodiniaceae reside in the gastrodermis but are found in the mucus as well [56,57]. Intracellular bacteria and cell-associated microbial aggregates can occur in both cellular layers. Symbiodiniaceae cells have also been reported to harbor intracellular bacteria [51]. Other microorganisms, including viruses [58], archaea [59], fungi [60], and other eukaryotes [61,62], associate with corals and are not represented in this figure.

\section{The Search for Intracellular Bacteria}

Fifty-five years ago, Paul Buchner provided one of the most comprehensive bodies of work describing endosymbiosis in insects as well as in a few mollusks and fishes, using only light microscopy [14]. This seminal study was conducted long before electron microscopy, fluorescence microscopy, and DNA sequencing were accessible. Despite the availability of such modern techniques, observations of intracellular bacteria are still scarce in cnidarians. Certain intracellular bacteria were observed with fluorescent microscopy (via fluorescence in situ hybridization (FISH)) and electron microscopy in the epithelial cells of Montastraea cavernosa [48]; in the gastrodermal cells of Acropora granulosa [43], Acropora cervicornis, Acropora hyacinthus, and Acropora cytherea [49,50]; and in Symbiodiniaceae cells, both in culture and freshly isolated from the coral Galaxea faciscularis and the sea anemone Exaiptasia diaphana [51]. However, no bacteria-housing structures have been described in corals so far, which has made in situ localization challenging as individual bacteria or bacterial clusters might not be detected by conventional methods or could easily be regarded as artefacts. By contrast, most insects house their endosymbionts in specialized cells, called bacteriocytes, that sometimes group together in an organ, the bacteriome [14,63] (Figure 2A). Within bacteriocytes, bacterial density is very high, as these cells are usually filled with endosymbionts, hence being highly visible even with light microscopy. This 'compartmentalization' is believed to have evolved independently in many insect lineages, as it is found in widely divergent orders and exhibits great morphological variability (Figure 2B-C). Similar specialized, endosymbiont-filled cells have also been described in platyhelminths [64] and annelids [65], in an organ called the trophosome (Figure 2D). Interestingly, it was shown in tubeworms that the trophosome originates from mesodermal tissue [66]. The absence of a mesodermal tissue layer during cnidarian embryonic development, which possess the largely acellular mesoglea layer 
instead, could explain the absence of specialized morphological structures that house endosymbionts.

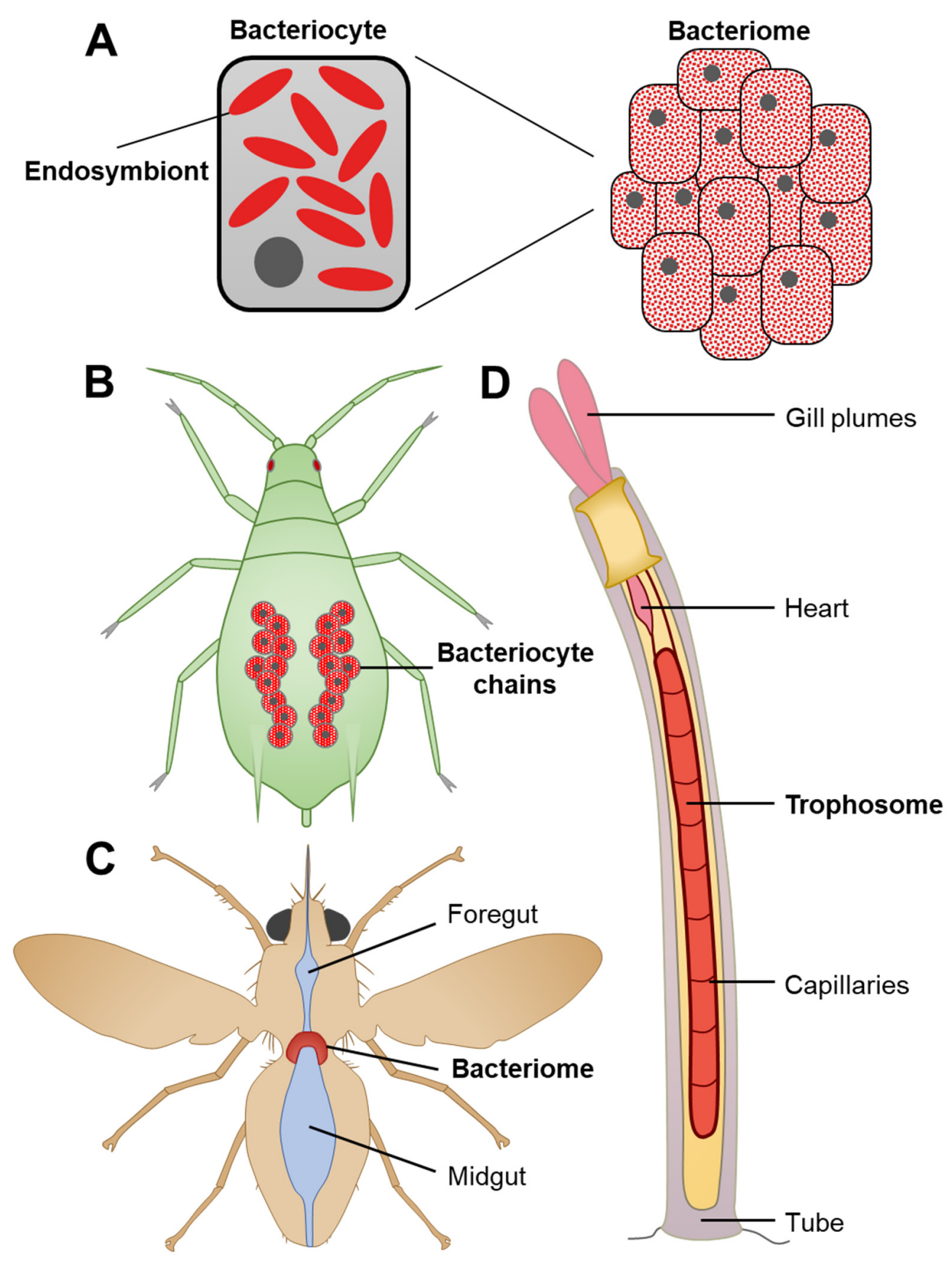

Figure 2. Morphological diversity of symbiotic structures. In organisms such as insects, high densities of endosymbionts are housed in specialized host cells, called bacteriocytes, that sometimes form a dedicated organ, the bacteriome (A). In the pea aphid A. pisum, giant bacteriocytes (diameter $>100 \mu \mathrm{m}$ in adults) are grouped in two abdominal chains (B) [14]. They house B. aphidicola, which provides most essential amino acids to its sap-feeding host [63]. In the tsetse fly Glossina morsitans, bacteriocytes form a bacteriome around the gut (C) [67]. Its endosymbiont Wigglesworthia glossinidia synthesizes B vitamins that are absent in the fly's hematophagous diet [68]. In the tube worm Riftia pachyptila, bacteriocytes form a trophosome that is directly linked to the circulatory system (D). This tubeworm species usually lives near hydrothermal vents. Carbon dioxide and hydrogen sulfide are internalized by the plume gills and transferred through the circulatory system to the trophosome, where chemosynthetic endosymbionts are able to metabolize those dissolved gases and to provide organic matter to their host [16]. 
Nonetheless, in a wide range of coral species, structures called cell-associated microbial aggregates (CAMAs) have been observed, both in the epidermis and the gastrodermis [44,69-75] (Figure 1). In the coral A. hyacinthus, CAMAs were present in all observed tissues: tentacles, actinopharynx, mesentery, mesenterial filaments, coenenchyma, and calicodermis [70]. In Porites compressa, transmission electron microscopy revealed that CAMAs were sometimes surrounded by what appeared to be a membrane, suggesting an intracellular location [72]. Similarly, in the cnidarian model, the sea anemone Exaiptasia diaphana, CAMAs observed in tentacles seemed to be contained within vacuoles, which were intracellular when the CAMA was small and extracellular when the CAMA was big (i.e., bigger than a regular anemone cell) [76]. The possible intracellular nature of these aggregates therefore makes them of great interest; however, there is little known besides their description and localization. More detailed work, especially electron microscopy and DNA sequencing, should be undertaken to determine the exact subcellular location and taxonomic affiliation of these aggregates. The mechanisms behind their formation are also unknown and should be investigated, as it could involve bacterial signals (e.g., quorumsensing and chemotaxis), host signals, or a combination of both. In the legume-Rhizobium symbiosis [18], Rhizobium present in the soil are attracted by flavonoids produced by the host plant and released in the environment. In response, Rhizobium secretes Nod factors that are recognized by the host plant and trigger signaling cascades leading to the formation of root hair curls that essentially trap Rhizobium. From there, Rhizobium move towards the plant root cells, infect them, and finally trigger the formation of specialized nodules, a structure that bears resemblance with CAMAs. Similarly, chitin and chitobiose were identified as chemoattractants in the association between the squid Euprymna scolopes and the luminescent extracellular bacterium Vibrio fischeri [77]. Indeed, a gradient of chitobiose lures environmental $V$. fischeri into the squid [77], where it triggers the maturation of a so-called light organ [78], although it remains extracellular. Cells of Endozoicomonas montiporae, isolated from Montipora aequituberculata, formed aggregates in vitro when provided with dimethylsulfoniopropionate (DMSP) as a carbon source, forming structures similar to CAMAs [79]. This indicates that metabolites potentially originating from the coral host and/or Symbiodiniaceae could initiate CAMA formation.

Symbiodiniaceae cells are also a microhabitat of high interest, as algae-bacteria interactions have been widely described (Box 1). In fact, Symbiodiniaceae-associated bacteria were recently shown to be abundant, both extracellularly and intracellularly, in cultured Symbiodiniaceae and in Symbiodiniaceae freshly isolated from two cnidarians [51]. Intracellular bacterial communities showed great similarity across Symbiodiniaceae species, suggesting they might have conserved functions in these algae [51]. Additionally, the phycosphere of free-living Symbiodiniaceae, the extracellular layer around the cell composed of algal exudates such as organic carbon, may attract and support bacterial metabolism and growth [80-82]. If similar mechanisms occur in hospite, these might attract bacteria into the gastrodermal cells. As Symbiodiniaceae cells are of a similar size to their host cells, bacteria entering gastrodermal cells would be in immediate contact with Symbiodiniaceae, hence facilitating interactions. Some metabolites are expected to cross the multiple symbiosomal membranes and to facilitate Symbiodiniaceae-bacteria communication; however, such metabolites and the mechanisms behind their exchange between Symbiodiniaceae and bacteria remain uninvestigated. In line with this, cyanobacteria-like structures were shown to be abundant in gastrodermal cells and in close proximity with Symbiodiniaceae in A. hyacinthus and A. cytherea [50]. Symbiodiniaceae-bacteria interactions have seen growing interest in recent years and have been suggested as a potentially critical factor in Symbiodiniaceae-and in turn coral-health [83-86] (Box 1), but any proven functions of intracellular bacteria housed in Symbiodiniaceae, either in culture or in hospite, that could be interpreted as mutualistic remain to be determined. 
Box 1. Algae-bacteria interactions.

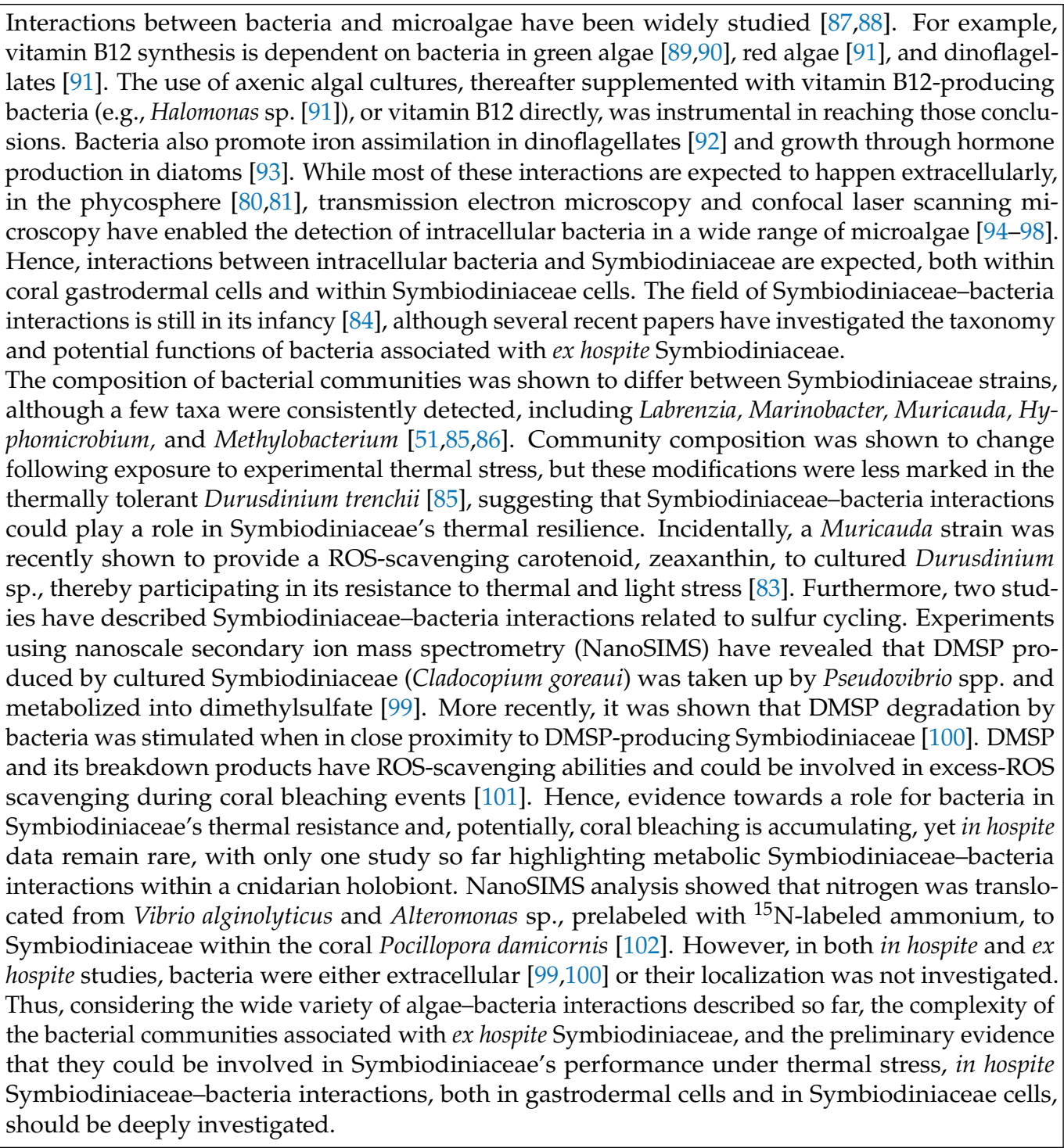

Finally, as mutualistic intracellular bacteria are likely to be vertically transmitted from parent to offspring [12], coral gonads and gametes should be studied for the presence of intracellular bacteria as well. Corals possess two modes of sexual reproduction: broadcast spawning and brooding. Broadcasters release eggs and sperm into the water column for external fertilization and development; brooders release sperm that internally fertilize eggs within polyps, and brood larvae until maturity [103]. Coral gonads—spermeries and ovaries-form anew at each reproductive cycle in the endodermal mesenteries [104]. In insects, endosymbiont vertical transmission is often achieved through a persistent bacterial population present in the reproductive organs, often in females $([67,105-108]$, but see [109] for a case of paternal transmission). Endosymbionts often infect the egg during oogenesis $[63,105,108]$ or are deposited on the egg after oviposition via capsules or jellies [110]. As coral gonads are transient, it is unlikely that they would possess a persistent bacterial population able to infect gametes. Nonetheless, the mesentery portions where gonad formation and gametogenesis occur should be investigated through FISH and 16S rRNA gene metabarcoding for the presence of bacteria that might be vertically transmitted through gametes. Several 16S rRNA gene metabarcoding studies in broadcasters have shown the presence of shared bacteria between adults and gametes/early life developmental stages [111,112], suggesting the vertical transmission of some bacterial associates. 
However, FISH experiments have thus far not detected the presence of bacteria in the gametes of broadcasters [111,112], prompting the hypothesis that bacteria might be transferred through mucus present on the surface of egg-sperm bundles [113], which would be lost during classical FISH fixation procedures with aqueous paraformaldehyde. Water-free fixation methods, such as Carnoy's solution [114], should be employed to preserve the mucus and to test this hypothesis. Interestingly, both $16 \mathrm{~S}$ rRNA gene metabarcoding and FISH experiments revealed vertical transmission of bacteria in larvae of the asexual brooder Pocillopora acuta [71]. The situation is reminiscent of the tsetse fly G. morsitans, which also broods larvae one at a time until it reaches maturity and transmits its primary endosymbiont $W$. glossinidius through milk secretions that feed the developing larvae [115]. Symbionts might be fed and vertically transmitted in a similar way to developing planulae in brooding corals.

\section{The Identification of Intracellular Bacteria}

The identification of intracellular bacteria has always been a challenging task. Due to their intracellular lifestyle and potentially high level of dependence on their hosts, most endosymbionts are not pure-culturable. Indeed, some vertically transmitted endosymbionts are known to have undergone massive genome shrinkage (Box 2). Endosymbiont genes encoding metabolic pathways that are redundant when in hospite are often lost, leading to complete dependency on the host for proper functioning and survival [12]. Culturing procedures that require cell or tissue passaging have proved successful. For example, Chlamydiae and Mycobacterium leprae depend on host cells to replicate and are successfully grown in the lab in amoebae and armadillos, respectively [116,117]. Culture-independent techniques, such as 16S rRNA gene metabarcoding, have also been widely applied to identify coral-associated bacteria [118]. However, extracellular and intracellular bacteria cannot be distinguished in metabarcoding analyses, unless their taxonomic affiliation places them in known intracellular taxa. For example, Candidatus Aquarickettsia rowheri, a novel member of the Rickettsiales order (known to be obligate intracellular bacteria), have been found to widely associate with corals [49]. However, this bacterium has been linked to coral dysbiosis as it is thought to thrive off excess inorganic nitrogen, subsequently taking up host resources, slowing coral growth and increasing disease susceptibility and mortality $[49,119,120]$. Unlike most mutualistic endosymbionts, Ca. A. rowheri is not vertically transmitted [121], although it is not uncommon for intracellular pathogens to spread horizontally [122]. Simkaniaceae, belonging to the intracellular Chlamydiales order, have also been reported in high abundances in several coral [112,123-125] and Symbiodiniaceae species [51], although these bacteria might be associated with protists present in the samples. Endosymbiont identification in insects has been largely facilitated by their typically very low diversity, with one bacterial species usually being exclusively associated with one insect species [126] and by them being condensed in bacteriocytes and bacteriomes. Crude extracts of bacteriomes have often been enough to identify the single bacterial species housed in this organ. To identify bacteria that are likely important for holobiont functioning and health, a 'coral core microbiome' approach was recently proposed to identify bacteria that persist across samples (e.g., of a same coral species, a same reef, etc.) [127]. However, all mutualistic species in a holobiont are present due to not only their taxonomic identity but also their functional roles. Different holobionts might house different bacterial taxa that provide the same functions in every holobiont. To avoid missing potentially important functions supported by bacteria of different taxonomic affiliations, a better concept would therefore be the 'core microbiome function'. 
Box 2. Genome evolution in bacterial endosymbionts.

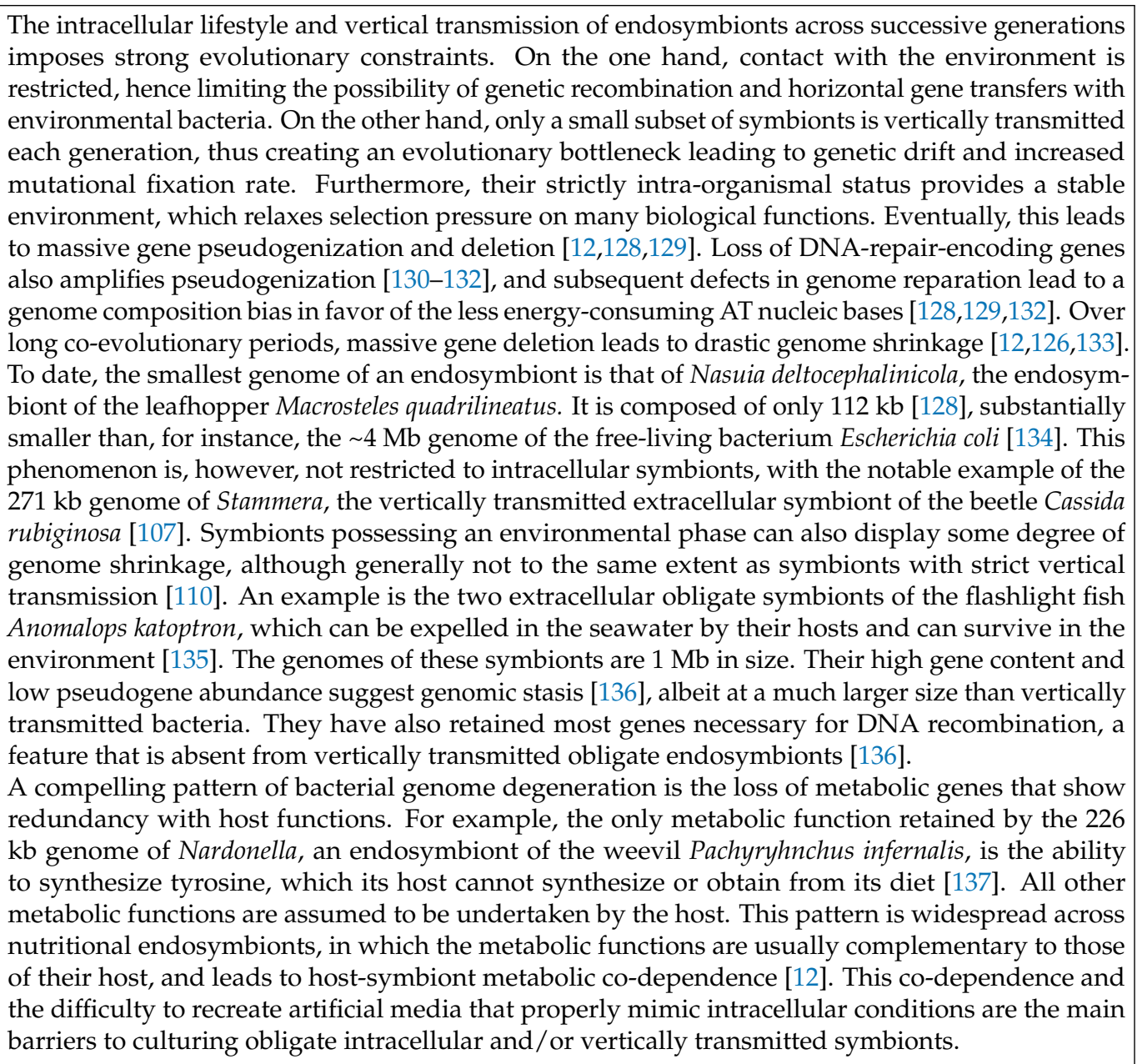

Thus, we recommend applying the 'core microbiome' approach to the identification of intracellular bacteria that stably associate with corals, as widespread intracellular symbionts are more likely to bear significant functions. In order to eliminate extracellular bacteria and have the ability to link putative bacterial functions with their tissue of origin, organs or tissue layers must be studied independently from one another. Laser capture microdissection (LCM) has recently emerged as a tool enabling such studies, allowing for the separation of groups of cells. Ainsworth et al. (2015) applied this technique to identify bacteria associated with gastrodermal cells (i.e., cells also harboring Symbiodiniaceae), that are therefore putatively intracellular [43]. It was concluded that bacterial communities in the gastroderm differed significantly from those of the whole coral and that abundant, core intracellular bacteria, Ralstonia sp. and Cutibacterium sp. (formerly Propionibacterium sp.), were under-represented in whole coral communities, confirming the need to study bacterial communities at the sub-organismal level [43]. However, both Ralstonia and Cutibacterium are commonly found in negative controls and reported as contaminants [138,139], and could be over-represented in low-biomass samples, such as samples from LCM experiments. As negative controls were not reported [43], it remains unknown whether Ralstonia and Cutibacterium are contaminants or true intracellular bacteria. This same study also explored the microbiome of tissue layers only, i.e., the gastroderm, the epithelium, and the mesoglea, although LCM was not used to separate these tissues, and surface or interstitial bacteria could have contaminated these samples. Nonetheless, separating cells from specific microhabitats, through LCM or even manual dissection when possible, should be encouraged in the future to identify intracellular bacteria and to discriminate them from extracellular bacteria. 
Finally, once presumed intracellular bacteria are identified, their long-term presence in an organism and in related species must be assessed, as endosymbionts that persist over time and under changing environments are more likely to bear biological and ecological significance. For example, cyanobacteria-like structures were abundantly observed in gastrodermal cells of $A$. hyacinthus and $A$. cytherea both in summer and in winter, indicating a degree of stability in this association [50]. In most insects, endosymbionts are present in $100 \%$ of populations, e.g., Blochmannia in the carpenter ant Camponotus spp. [140] or Tremblaya in mealybugs [141], and have been co-evolving with their hosts for millions of years. As such, endosymbionts have been vertically transmitted over the course of many speciation events within insect groups-co-diversification, resulting in phylogenetic congruence or cophylogeny between hosts and endosymbionts. Correlations between the phylogeny of hosts and their associated bacteria have been reported in corals, in particular for tissueand skeleton-associated bacteria, i.e., closely associated symbionts [142-144]. However, as symbiont stability and mode of transmission are mostly unknown, co-evolution cannot be assumed. Hence, future work should be focused on identifying intracellular bacteria, assessing whether they are vertically transmitted and stable throughout their host's life cycle and evaluating their presence in a wide range of related coral species to examine coral-bacteria co-evolution.

\section{The Assessment of the Roles of Intracellular Bacteria within the Coral Holobiont}

Thus far, proven bacterial functions in corals are mostly related to extracellular bacteria or bacteria of unknown location and studies often relied on culture-dependent techniques. For example, bacteria associated with Acropora palmata were shown to produce antibiotics that could potentially protect their coral hosts from pathogens [145]. These bacteria were isolated from coral mucus and are thus extracellular [145]. Similarly, many bacterial functions were inferred from the analysis of whole genomes, which, based on their large sizes, are likely to come from extracellular bacteria [146]. The most compelling evidence of bacterial involvement in nitrogen cycling in corals comes from nanoSIMS data, involving bacterial culturing, stable-isotope $\left({ }^{15} \mathrm{~N}\right)$ labelling, and reinoculation to corals [102,147]. Such experiments are unlikely to work with intracellular bacteria. Nonetheless, a series of in situ experiments have shown (i) the presence of intracellular cyanobacteria in the coral M. cavernosa [48]; (ii) their ability to produce nitrogenases, through immunoblotting and immunogold labelling [48]; and (iii) a higher rate of nitrogen fixation, via the acetylene reduction assay, in corals associated with cyanobacteria when compared with corals of the same species lacking cyanobacteria [148]. To our knowledge, this is the only functional study of a coral-associated intracellular bacterium.

A crucial aspect in assessing the function of intracellular, non-pure-culturable bacteria is the possibility of collecting or generating individuals lacking the bacteria, as exemplified by Lesser et al. (2007), who sampled and compared corals of the same species (M. cavernosa) and from the same depth, which differed in their association with intracellular cyanobacteria [148]. Comparative analyses of organisms that contain or lack specific intracellular symbionts can thus give insight in the function of the symbiont. This approach has been widely used in insects, particularly with endosymbionts involved in metabolic complementation. For example, the African tick Ornithodoros moubata associates with intracellular bacteria of the genus Francisella [149]. Francisella endosymbionts were removed from the ticks using antibiotics, and these aposymbiotic ticks were reported to have lower nymph emergence rates, lower mass, and physical abnormalities (darker and inflated bodies) [149]. These hampered phenotypes were rescued by the supplementation of the aposymbiotic tick's diet with B vitamins, a nutrient that is in low abundance in the natural tick's diet (mammal blood), hence showing that Francisella is involved in B vitamin metabolism [149]. However, this approach relies on easily observable differences between symbiotic and aposymbiotic animals, and options to rescue endosymbiont functions (e.g., B vitamins in ticks). Furthermore, antibiotic-driven depletion of endosymbionts in corals, which associate with highly diverse bacterial communities, would also affect extracellular symbionts. 
An alternative approach may be to try to generate completely axenic organisms and then to re-inoculate them with specific bacteria of interest, although antibiotic treatments have so far had limited success [150].

With the advent of high throughput sequencing, many tools are now available for specific, functional, in hospite studies of non-pure-culturable endosymbionts. The first published genome of a mutualistic endosymbiont was that of B. aphidicola, endosymbiont of the pea aphid A. pisum [151]. It confirmed the findings of metabolic complementation experiments: $B$. aphidicola can synthesize all essential amino acids and can provide them to its insect host. It also provided a first glimpse into signatures of genome reduction in obligate intracellular bacteria (Box 2), which were confirmed after the publication of dozens of genomes from obligate endosymbionts [126,152]. Assessing such genome degeneration signatures, e.g., reduced size, base composition bias, and high abundance of pseudogenes, in coral-associated bacteria would help in identifying host-dependent and potentially vertically transmitted endosymbionts. Endosymbiont transcriptomics are also becoming more common, with the dual-RNAseq approach, i.e., the simultaneous analysis of host and endosymbiont transcriptomes, gaining traction in recent years [153-156]. While dual-RNAseq has been applied to study coral-Symbiodiniaceae transcriptomes [157], bacterial transcriptomics are still understudied, mostly because of the high bacterial diversity in corals, the relatively low abundance of bacterial mRNAs compared with eukaryotic mRNAs, and the high costs of rRNA and poly-A tailed mRNA depletion approaches. We must move towards meta-omics to capture the taxonomic, genetic, and functional diversity of intracellular bacteria in corals, ideally coupled with symbiont-containing coral cell enrichment approaches or intracellular bacteria-sorting methods (Figure 3). For example, the genome of the intracellular coral bacterium $C a$. A. rowheri was obtained through shotgun sequencing of a coral sample, which confirmed its reduced genome size, its inability to produce most amino acids and ATP and thus to replicate on its own, as well as its ability to sense extracellular nitrogen [49]. The latter was hypothesized to participate in the bacterium's ability to reduce coral health when nitrogen is in excess. Meta-omics data would provide insight into designing suitable culture conditions, including specific metabolites that are needed to obtain pure cultures of coral intracellular symbionts [158]. Obtaining endosymbionts in pure culture could be challenging but not unfeasible. Indeed, a handful of insect endosymbionts have been successfully pure cultured using supplemented media based on their host's diet [159-163]. For instance, Sodalis glossidinius, an intracellular symbiont (although it is also found extracellularly in its host [164]) of the tsetse fly G. morsitans, was initially cultured on agar media supplemented with horse blood [160]. Similarly, coral-associated bacteria have been maintained in coral cell-free culture fluid (i.e., sterilized coral homogenates), and the health state of the coral was shown to influence bacterial growth [165]. Intracellular bacteria may be able to be isolated using such a technique, and metabolic analyses of cell-free culture fluids may provide additional insights in the metabolites that are necessary for the growth of intracellular bacteria. Successful culturing of bacterial endosymbionts of corals, based on genomic and transcriptomic data, would open a wide avenue of applications. 

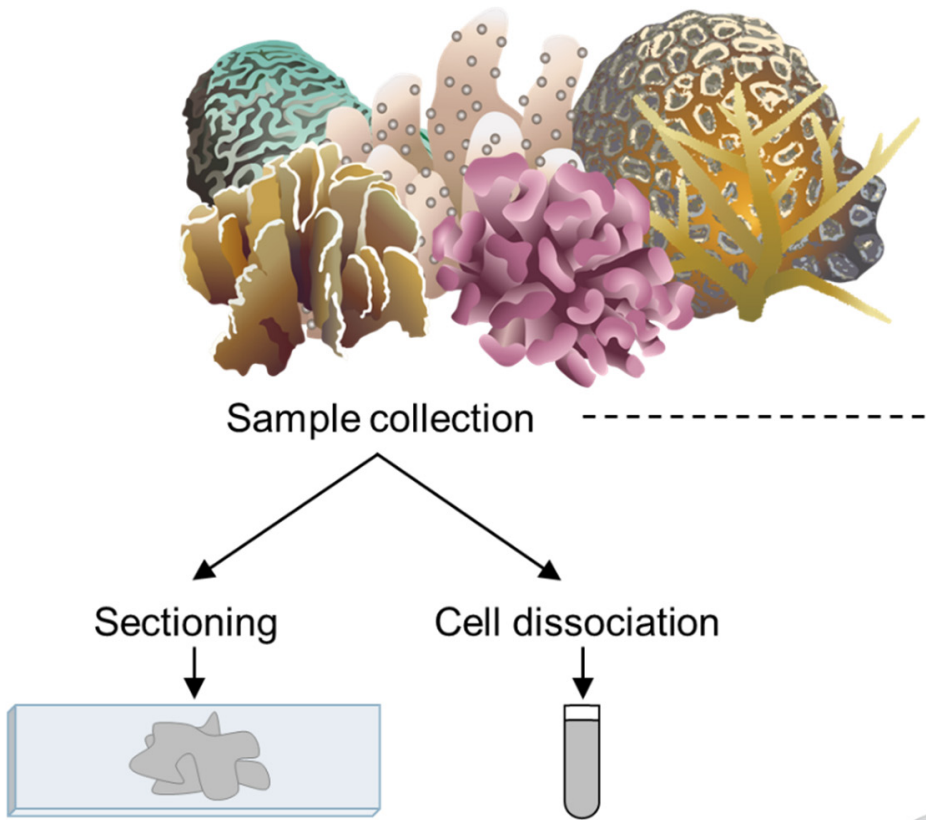

Cell dissociation
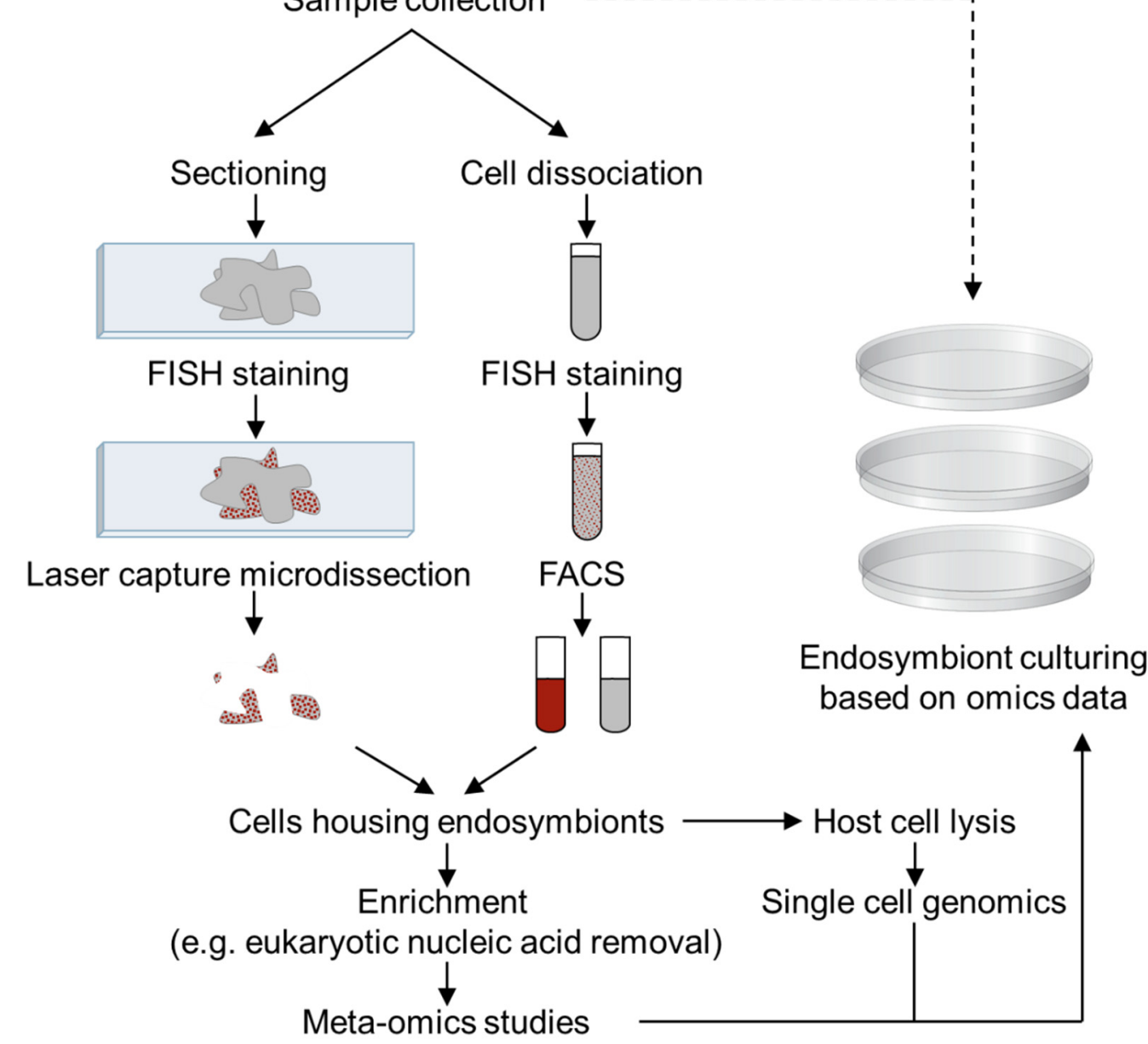

Figure 3. Proposed workflow for meta-omics studies of coral-associated endosymbionts. To optimize meta-omics studies in coral endosymbionts, we recommend the use of techniques allowing for the selection of cells harboring endosymbionts. FISH can be used on tissue sections to highlight endosymbionts, and LCM can allow for the capture of cells harboring them (left). Alternatively, coral cells can be dissociated, stained by FISH, and sorted through FACS (middle) [166]. This would maximize the abundance of bacterial reads in subsequent meta-omics studies. These symbiont-housing coral cells can then be lysed to release intracellular bacteria that can be sorted and individually sequenced through single cell genomics. Furthermore, omics data would give insight into the conditions needed for the culture of coral endosymbionts (right). Coral and plate images courtesy of the Integration and Application Network (ian.umces.edu/symbols/, accessed on 26 May 2020).

\section{Applications Involving Coral-Associated Intracellular Bacteria to Help Save Coral Reefs}

Beyond understanding the fundamental aspects of intracellular symbiosis, hostendosymbiont interactions and co-evolution, mutualistic intracellular symbionts bear great interest in the applied sciences, particularly in the microbiome manipulation field. Microbiome manipulation is one of several avenues that are currently being pursued in 
order to mitigate coral bleaching $[40,53,54,167-170]$. As excess ROS production by Symbiodiniaceae is one of the main causes of coral bleaching [34,36-38], it was postulated that treating corals with bacteria with a high ROS-scavenging ability could mitigate coral bleaching [171]. Proof of concept studies have confirmed that the coral microbiome can be modified [172,173], without specifically targeting ROS scavenging, but only three studies so far have actually trialed probiotics to mitigate coral bleaching [174-176]. Some of the major potential caveats are as follows: (i) will the bacteria persist in the corals, or should probiotics be applied regularly/during every bleaching event? and (ii) how can the inoculated bacteria be prevented from spreading in the surrounding waters and organisms and potentially disrupting other parts of the ecosystem? Establishing specific associations with vertically transmitted, intracellular bacteria would solve both issues. This approach has been implemented by using Wolbachia in the mosquito Aedes aegypti to reduce the transmission of arboviruses, including viruses causing dengue, chikungunya, and Zika [177]. Wolbachia is an intracellular $\alpha$-proteobacterium that is estimated to naturally infect $40-60 \%$ of insect species $[178,179]$. Its transmission through host generations is mainly maternal through their eggs, and its dispersion is highly enhanced by several mechanisms that impact host reproduction, with the main one being cytoplasmic incompatibility. Infected females can mate with both uninfected and infected males, leading to Wolbachia transmission, but mating between an infected male and an uninfected female, i.e., not resulting in Wolbachia transmission, leads to offspring loss [180]. Wolbachia was initially reported to provide viral protection to Drosophila melanogaster [181] and was subsequently shown to prevent the transmission of a wide range of human arboviruses in A. aegypti by inhibiting pathogen replication [182-184]. This Wolbachia strain had to be stably introduced into $A$. aegypti laboratory populations $[184,185]$, which do not naturally associate with Wolbachia. Early fieldwork trials in northern Australia have shown that, following the release of Wolbachia-infected mosquitos in the wild, Wolbachia has established in the wild uninfected populations, reaching around $90 \%$ of the populations [186-188]. Furthermore, dengue transmission has significantly decreased in these regions $[177,188]$. Hence, microbiome manipulation using an intracellular bacterium has been particularly successful in this example and has provided crucial advantages compared to an extracellular bacterium: Wolbachia has spread quickly and efficiently in wild populations following a unique release of infected mosquitos and has remained stable over the years; the risk of horizontal transmission to other animals, including humans, is very low [189]. As a long-term solution for coral bleaching mitigation, coral microbiome manipulation with intracellular bacteria should therefore be pursued.

Finally, if intracellular symbionts can be pure cultured, this will open the possibility of genetic engineering aimed at introducing specific traits of interest that might not be naturally present in the intracellular bacterial strain of interest. A recent proof of concept study has shown the possibility of transforming Spiroplasma poulsonii, an endosymbiont of $D$. melanogaster, via plasmids [190]. These promising results indicate that commonly used genetic engineering tools can be applied to intracellular bacteria. However, genetic modification of symbionts and reintroduction in a host, also referred to as paratransgenesis, has only been performed with extracellular bacteria. For example, gut symbionts of the triatomine bug Triatoma infestans, the vector of the Chagas' disease pathogen Trypanosoma cruzi, were genetically modified to express antimicrobial peptides or antibody fragments, efficiently reducing T. cruzi numbers when reintroduced in trypanosome-infected hosts [191,192]. With a growing number of intracellular bacteria being successfully obtained in pure culture, this approach will surely be increasingly used in the coming years. Directed evolution is another approach that may allow for the generation of endosymbionts with enhanced abilities [54] and for which regulatory approval and public acceptance will be less challenging to obtain. Cultured Symbiodiniaceae (C. goreaui) were maintained for several years at a high temperature $\left(31^{\circ} \mathrm{C}\right.$, versus $27^{\circ} \mathrm{C}$ in normal conditions) and were subsequently shown to have better performance during a thermal stress event, both in culture and in hos- 
pite $[157,193]$. A similar approach could be used for pure-cultured bacterial endosymbionts to enhance their ability to favor thermal resilience in a coral host [54].

\section{Conclusions}

While intracellular bacteria have been widely studied in animals, particularly in insects, they remain under-investigated in corals. Great advancements have been made in recent years to understand the bacterial communities associated with corals, across a wide range of host species, developmental stages, and geographical locations. The same efforts should be sustained to specifically explore intracellular bacteria and to overcome the technical challenges that have slowed down this research area. Approaches that have proved fruitful in other systems will guide this research. Our specific recommendations are as follows:

- To characterize and localize stably associated bacteria and bacteria associated with gametes and temporary gonads as a starting point in the search for intracellular and vertically transmitted bacteria;

- To focus research on specific coral microhabitats and structures, such as Symbiodiniaceae and CAMAs to find intracellular bacteria, and to isolate successful microhabitats to perform meta-omics studies; and

- To use bacterial genome data to optimize culture media for attempting to grow intracellular bacteria in pure culture.

Information on the cellular location, transmission mode, taxonomic affiliation, and function of intracellular bacteria will allow us to characterize the most intimate hostbacteria interactions within the coral holobiont. From a fundamental perspective, it will be an opportunity to compare coral-bacteria intracellular interactions with more established systems, such as plants and insects, and to assess whether specific mechanisms are conserved across such divergent taxa. From an applied point of view, successfully cultured intracellular bacteria would make ideal candidates for coral microbiome manipulation to try and mitigate coral bleaching. In particular, if genetic engineering were to be considered, symbionts that are vertically transmitted and that show little to no contact with the surrounding environments would have to be used to avoid a potential spread of genetically modified bacteria beyond the coral host. Endosymbiosis is an exciting and promising field and should not be left aside in cnidarians, especially in the quest to reduce the negative impacts of global climate change on coral reefs.

Author Contributions: J.M. wrote the first draft with significant input from L.L.B. and M.J.H.v.O. All authors have read and agreed to the published version of the manuscript.

Funding: This work was supported by the Australian Research Council Laureate Fellowship FL180100036 to MJHvO.

Institutional Review Board Statement: Not applicable.

Data Availability Statement: Not applicable.

Conflicts of Interest: The authors declare that they have no competing interests.

\section{References}

1. Frank, A.B. Uber die biologischen Verhältnisse des Thallus eineger Krustenflechnten. Beitr. Biol. Pflanz. 1877, 2, 123-200.

2. De Bary, A. Die Erscheinung der Symbiose. Revur Inter. Sci 1879, 3, 301-309.

3. Sachs, J.L.; Skophammer, R.G.; Regus, J.U. Evolutionary transitions in bacterial symbiosis. Proc. Natl. Acad. Sci. USA 2011, 108, 10800-10807. [CrossRef] [PubMed]

4. Brown, B.L.; Creed, R.P.; Skelton, J.; Rollins, M.A.; Farrell, K.J. The fine line between mutualism and parasitism: Complex effects in a cleaning symbiosis demonstrated by multiple field experiments. Oecologia 2012, 170, 199-207. [CrossRef] [PubMed]

5. Mandyam, K.G.; Jumpponen, A. Mutualism-parasitism paradigm synthesized from results of root-endophyte models. Front. Microbiol. 2015, 5, 776. [CrossRef]

6. Pérez-Brocal, V.; Latorre, A.; Moya, A. Symbionts and pathogens: What is the difference? Curr. Top. Microbiol. Immunol. 2013, 358, 215-243. [CrossRef] 
7. Canestrari, D.; Bolopo, D.; Turlings, T.C.J.; Röder, G.; Marcos, J.M.; Baglione, V. From parasitism to mutualism: Unexpected interactions between a cuckoo and its host. Science 2014, 343, 1350-1352. [CrossRef]

8. Sagan, L. On the origin of mitosing cells. J. Theor. Biol. 1967, 14, 225-IN6. [CrossRef]

9. McFall-Ngai, M.; Hadfield, M.G.; Bosch, T.C.G.; Carey, H.V.; Domazet-Lošo, T.; Douglas, A.E.; Dubilier, N.; Eberl, G.; Fukami, T.; Gilbert, S.F.; et al. Animals in a bacterial world, a new imperative for the life sciences. Proc. Natl. Acad. Sci. USA 2013, 110, 3229-3236. [CrossRef]

10. Moran, N.A. Symbiosis as an adaptive process and source of phenotypic complexity. Proc. Natl. Acad. Sci. USA 2007, 104, 8627-8633. [CrossRef]

11. Douglas, A.E. Endosymbionts and intracellular parasites. In Encyclopedia of Microbiology; Elsevier Inc.: Amsterdam, The Netherlands, 2009; pp. 128-141. ISBN 9780123739445.

12. Bennett, G.M.; Moran, N.A. Heritable symbiosis: The advantages and perils of an evolutionary rabbit hole. Proc. Natl. Acad. Sci. USA 2015, 112, 10169-10176. [CrossRef]

13. McCutcheon, J.P. From microbiology to cell biology: When an intracellular bacterium becomes part of its host cell. Curr. Opin. Cell Biol. 2016, 41, 132-136. [CrossRef]

14. Buchner, P. Endosymbiosis of Animals with Plant Microorganisms; Interscience Publishers: New York, NY, USA; John Wiley: New York, NY, USA, 1965.

15. Baumann, P.; Moran, N.A.; Baumann, L.C. Bacteriocyte-associated endosymbionts of insects. In The Prokaryotes; Springer: Berlin/Heidelberg, Germany, 2013; pp. 465-496.

16. Dubilier, N.; Bergin, C.; Lott, C. Symbiotic diversity in marine animals: The art of harnessing chemosynthesis. Nat. Rev. Microbiol. 2008, 6, 725-740. [CrossRef] [PubMed]

17. Franke, M.; Geier, B.; Hammel, J.; Dubilier, N.; Leisch, N. Coming together-symbiont acquisition and early development in deep-sea bathymodioline mussels. Proc. Biol. Sci. 2021, 288, 20211044. [CrossRef] [PubMed]

18. Haag, A.F.; Arnold, M.F.F.; Myka, K.K.; Kerscher, B.; Dall'Angelo, S.; Zanda, M.; Mergaert, P.; Ferguson, G.P. Molecular insights into bacteroid development during Rhizobium-legume symbiosis. FEMS Microbiol. Rev. 2013, 37, 364-383. [CrossRef] [PubMed]

19. Pawlowski, K.; Demchenko, K.N. The diversity of actinorhizal symbiosis. Protoplasma 2012, 249, 967-979. [CrossRef] [PubMed]

20. Nowack, E.C.M.; Melkonian, M. Endosymbiotic associations within protists. Philos. Trans. R. Soc. B Biol. Sci. 2010, 365, 699-712. [CrossRef] [PubMed]

21. Nakabachi, A.; Shigenobu, S.; Sakazume, N.; Shiraki, T.; Hayashizaki, Y.; Carninci, P.; Ishikawa, H.; Kudo, T.; Fukatsu, T. Transcriptome analysis of the aphid bacteriocyte, the symbiotic host cell that harbors an endocellular mutualistic bacterium, Buchnera. Proc. Natl. Acad. Sci. USA 2005, 102, 5477-5482. [CrossRef]

22. Douglas, A.E.; Smith, D.C. Are endosymbioses mutualistic? Trends Ecol. Evol. 1989, 4, 350-352. [CrossRef]

23. Garcia, J.R.; Gerardo, N.M. The symbiont side of symbiosis: Do microbes really benefit? Front. Microbiol. 2014, 5, 510. [CrossRef]

24. Maire, J.; Vincent-Monégat, C.; Balmand, S.; Vallier, A.; Hervé, M.; Masson, F.; Parisot, N.; Vigneron, A.; Anselme, C.; Perrin, J.; et al. Weevil pgrp-lb prevents endosymbiont TCT dissemination and chronic host systemic immune activation. Proc. Natl. Acad. Sci. USA 2019, 116, 5623-5632. [CrossRef] [PubMed]

25. Anselme, C.; Vallier, A.; Balmand, S.; Fauvarque, M.-O.; Heddi, A. Host PGRP gene expression and bacterial release in endosymbiosis of the weevil Sitophilus zeamais. Appl. Environ. Microbiol. 2006, 72, 6766-6772. [CrossRef] [PubMed]

26. Kiers, E.T.; Rousseau, R.A.; West, S.A.; Denison, R.F. Host sanctions and the legume-rhizobium mutualism. Nature 2003, 425, 78-81. [CrossRef]

27. Trench, R.K. Microalgal-invertebrate symbioses: A review. Endocytobiosis Cell Res. 1993, 9, 135.

28. Blackall, L.L.; Wilson, B.; van Oppen, M.J.H. Coral-the world's most diverse symbiotic ecosystem. Mol. Ecol. 2015, $24,5330-5347$. [CrossRef]

29. LaJeunesse, T.C.; Parkinson, J.E.; Gabrielson, P.W.; Jeong, H.J.; Reimer, J.D.; Voolstra, C.R.; Santos, S.R. Systematic revision of Symbiodiniaceae highlights the antiquity and diversity of coral endosymbionts. Curr. Biol. 2018, 28, 2570-2580.e6. [CrossRef]

30. Muscatine, L.; Porter, J.W. Reef corals: Mutualistic symbioses adapted to nutrient-poor environments. Bioscience 1977, 27, 454-460. [CrossRef]

31. Tremblay, P.; Grover, R.; Maguer, J.F.; Legendre, L.; Ferrier-Pagès, C. Autotrophic carbon budget in coral tissue: A new 13C-based model of photosynthate translocation. J. Exp. Biol. 2012, 215, 1384-1393. [CrossRef]

32. Spalding, M.D.; Ravilious, C.; Green, E.P. World Atlas of Coral Reefs. Prepared at the UNEP World Conservation Monitoring Centre; University of California Press: Berkeley, CA, USA, 2001; ISBN 0-520-23255-0.

33. Fisher, R.; O'Leary, R.A.; Low-Choy, S.; Mengersen, K.; Knowlton, N.; Brainard, R.E.; Caley, M.J. Species richness on coral reefs and the pursuit of convergent global estimates. Curr. Biol. 2015, 25, 500-505. [CrossRef] [PubMed]

34. Weis, V.M. Cellular mechanisms of Cnidarian bleaching: Stress causes the collapse of symbiosis. J. Exp. Biol. 2008, 211, 3059-3066. [CrossRef] [PubMed]

35. Suggett, D.J.; Smith, D.J. Coral bleaching patterns are the outcome of complex biological and environmental networking. Glob. Chang. Biol. 2020, 26, 68-79. [CrossRef]

36. Lesser, M.P. Elevated temperatures and ultraviolet radiation cause oxidative stress and inhibit photosynthesis in symbiotic dinoflagellates. Limnol. Oceanogr. 1996, 41, 271-283. [CrossRef] 
37. Lesser, M.P. Oxidative stress causes coral bleaching during exposure to elevated temperatures. Coral Reefs 1997, 16, 187-192. [CrossRef]

38. Downs, C.A.; Fauth, J.E.; Halas, J.C.; Dustan, P.; Bemiss, J.; Woodley, C.M. Oxidative stress and seasonal coral bleaching. Free Radic. Biol. Med. 2002, 33, 533-543. [CrossRef]

39. Hughes, T.P.; Anderson, K.D.; Connolly, S.R.; Heron, S.F.; Kerry, J.T.; Lough, J.M.; Baird, A.H.; Baum, J.K.; Berumen, M.L.; Bridge, T.C.; et al. Spatial and temporal patterns of mass bleaching of corals in the Anthropocene. Science 2018, 359, 80-83. [CrossRef] [PubMed]

40. van Oppen, M.J.H.; Blackall, L.L. Coral microbiome dynamics, functions and design in a changing world. Nat. Rev. Microbiol. 2019, 17, 557. [CrossRef] [PubMed]

41. Bourne, D.G.; Morrow, K.M.; Webster, N.S. Insights into the coral microbiome: Underpinning the health and resilience of reef ecosystems. Annu. Rev. Microbiol. 2016, 70, 317-340. [CrossRef]

42. Garren, M.; Azam, F. New method for counting bacteria associated with coral mucus. Appl. Environ. Microbiol. 2010, 76, 6128-6133. [CrossRef]

43. Ainsworth, T.D.; Krause, L.; Bridge, T.; Torda, G.; Raina, J.-B.; Zakrzewski, M.; Gates, R.D.; Padilla-Gamiño, J.L.; Spalding, H.L.; Smith, C.; et al. The coral core microbiome identifies rare bacterial taxa as ubiquitous endosymbionts. ISME J. 2015, 9, $2261-2274$. [CrossRef]

44. Neave, M.J.; Apprill, A.; Ferrier-Pagès, C.; Voolstra, C.R. Diversity and function of prevalent symbiotic marine bacteria in the genus Endozoicomonas. Appl. Microbiol. Biotechnol. 2016, 100, 8315-8324. [CrossRef]

45. Agostini, S.; Suzuki, Y.; Higuchi, T.; Casareto, B.E.; Yoshinaga, K.; Nakano, Y.; Fujimura, H. Biological and chemical characteristics of the coral gastric cavity. Coral Reefs 2012, 31, 147-156. [CrossRef]

46. Ricci, F.; Rossetto Marcelino, V.; Blackall, L.L.; Kühl, M.; Medina, M.; Verbruggen, H. Beneath the surface: Community assembly and functions of the coral skeleton microbiome. Microbiome 2019, 7, 159. [CrossRef] [PubMed]

47. Miller, A.W.; Blackwelder, P.; Al-Sayegh, H.; Richardson, L.L. Fine-structural analysis of black band disease infected coral reveals boring cyanobacteria and novel bacteria. Dis. Aquat. Organ. 2011, 93, 179-190. [CrossRef] [PubMed]

48. Lesser, M.P.; Mazel, C.H.; Gorbunov, M.Y.; Falkowski, P.G. Discovery of symbiotic nitrogen-fixing cyanobacteria in corals. Science 2004, 305, 997-1000. [CrossRef] [PubMed]

49. Klinges, J.G.; Rosales, S.M.; McMinds, R.; Shaver, E.C.; Shantz, A.A.; Peters, E.C.; Eitel, M.; Wörheide, G.; Sharp, K.H.; Burkepile, D.E.; et al. Phylogenetic, genomic, and biogeographic characterization of a novel and ubiquitous marine invertebrate-associated Rickettsiales parasite, Candidatus Aquarickettsia rohweri, gen. nov., sp. nov. ISME J. 2019, 13, 2938-2953. [CrossRef] [PubMed]

50. Kvennefors, E.C.E.; Roff, G. Evidence of cyanobacteria-like endosymbionts in Acroporid corals from the Great Barrier Reef. Coral Reefs 2009, 28, 547. [CrossRef]

51. Maire, J.; Girvan, S.K.; Barkla, S.E.; Perez-Gonzalez, A.; Suggett, D.J.; Blackall, L.L.; Van Oppen, M.J.H. Intracellular bacteria are common and taxonomically diverse in cultured and in hospite algal endosymbionts of coral reefs. ISME J. 2021, 15, $2028-2042$. [CrossRef]

52. Peixoto, R.S.; Sweet, M.; Villela, H.D.M.; Cardoso, P.; Thomas, T.; Voolstra, C.R.; Høj, L.; Bourne, D.G. Coral Probiotics: Premise, Promise, Prospects. Annu. Rev. Anim. Biosci. 2021, 16, 265. [CrossRef] [PubMed]

53. Epstein, H.E.; Smith, H.A.; Torda, G.; van Oppen, M.J. Microbiome engineering: Enhancing climate resilience in corals. Front. Ecol. Environ. 2019, 17, 100-108. [CrossRef]

54. Maire, J.; van Oppen, M.J.H. A role for bacterial experimental evolution in coral bleaching mitigation? Trends Microbiol. 2021. [CrossRef]

55. Peters, E.C. Anatomy. In Diseases of Coral; John Wiley \& Sons, Inc: Hoboken, NJ, USA, 2015; pp. 85-107.

56. Wright, R.M.; Strader, M.E.; Genuise, H.M.; Matz, M. Effects of thermal stress on amount, composition, and antibacterial properties of coral mucus. PeerJ 2019, 7, e6849. [CrossRef] [PubMed]

57. Nguyen-Kim, H.; Bettarel, Y.; Bouvier, T.; Bouvier, C.; Doan-Nhu, H.; Nguyen-Ngoc, L.; Nguyen-Thanh, T.; Tran-Quang, H.; Brune, J. Coral mucus is a hot spot for viral infections. Appl. Environ. Microbiol. 2015, 81, 5773-5783. [CrossRef]

58. Wood-Charlson, E.M.; Weynberg, K.D.; Suttle, C.A.; Roux, S.; van Oppen, M.J.H. Metagenomic characterization of viral communities in corals: Mining biological signal from methodological noise. Environ. Microbiol. 2015, 17, 3440-3449. [CrossRef] [PubMed]

59. Siboni, N.; Ben-Dov, E.; Sivan, A.; Kushmaro, A. Global distribution and diversity of coral-associated Archaea and their possible role in the coral holobiont nitrogen cycle. Environ. Microbiol. 2008, 10, 2979-2990. [CrossRef] [PubMed]

60. Amend, A.S.; Barshis, D.J.; Oliver, T.A. Coral-associated marine fungi form novel lineages and heterogeneous assemblages. ISME J. 2012, 6, 1291-1301. [CrossRef] [PubMed]

61. Kwong, W.K.; del Campo, J.; Mathur, V.; Vermeij, M.J.A.; Keeling, P.J. A widespread coral-infecting apicomplexan with chlorophyll biosynthesis genes. Nature 2019, 568, 103-107. [CrossRef] [PubMed]

62. Chakravarti, L.J.; Negri, A.P.; van Oppen, M.J.H. Thermal and herbicide tolerances of Chromerid algae and their ability to form a symbiosis with corals. Front. Microbiol. 2019, 10, 173. [CrossRef]

63. Baumann, P. Biology of bacteriocyte-associated endosymbionts of plant sap-sucking insects. Annu. Rev. Microbiol. 2005, 59, 155-189. [CrossRef] 
64. Dirks, U.; Gruber-Vodicka, H.R.; Leisch, N.; Bulgheresi, S.; Egger, B.; Ladurner, P.; Ott, J.A. Bacterial symbiosis maintenance in the asexually reproducing and regenerating flatworm Paracatenula galateia. PLoS ONE 2012, 7, e34709. [CrossRef]

65. Bright, M.; Giere, O. Microbial symbiosis in Annelida. Symbiosis 2005, 38, 1-45.

66. Nussbaumer, A.D.; Fisher, C.R.; Bright, M. Horizontal endosymbiont transmission in hydrothermal vent tubeworms. Nature 2006, 441, 345-348. [CrossRef]

67. Balmand, S.; Lohs, C.; Aksoy, S.; Heddi, A. Tissue distribution and transmission routes for the tsetse fly endosymbionts. J. Invertebr. Pathol. 2013, 112, S116-S122. [CrossRef]

68. Michalkova, V.; Benoit, J.B.; Weiss, B.L.; Attardo, G.M.; Aksoy, S. Vitamin B6 generated by obligate symbionts is critical for maintaining proline homeostasis and fecundity in tsetse flies. Appl. Environ. Microbiol. 2014, 80, 5844-5853. [CrossRef] [PubMed]

69. Peters, E.C. A survey of cellular reactions to environmental stress and disease in Caribbean scleractinian corals. Helgoländer Meeresunters. 1984, 37, 113-137. [CrossRef]

70. Wada, N.; Ishimochi, M.; Matsui, T.; Pollock, F.J.; Tang, S.-L.; Ainsworth, T.D.; Willis, B.L.; Mano, N.; Bourne, D.G. Characterization of coral-associated microbial aggregates (CAMAs) within tissues of the coral Acropora hyacinthus. Sci. Rep. 2019, 9, 14662. [CrossRef] [PubMed]

71. Damjanovic, K.; Menéndez, P.; Blackall, L.L.; van Oppen, M.J.H. Mixed-mode bacterial transmission in the common brooding coral Pocillopora acuta. Environ. Microbiol. 2020, 22, 397-412. [CrossRef] [PubMed]

72. Work, T.; Aeby, G. Microbial aggregates within tissues infect a diversity of corals throughout the Indo-Pacific. Mar. Ecol. Prog. Ser. 2014, 500, 1-9. [CrossRef]

73. Van De Water, J.A.J.M.; Ainsworth, T.D.; Leggat, W.; Bourne, D.G.; Willis, B.L.; van Oppen, M.J.H. The coral immune response facilitates protection against microbes during tissue regeneration. Mol. Ecol. 2015, 24, 3390-3404. [CrossRef]

74. Ainsworth, T.D.; Fine, M.; Blackall, L.L.; Hoegh-Guldberg, O. Fluorescence in situ hybridization and spectral imaging of coral-associated bacterial communities. Appl. Environ. Microbiol. 2006, 72, 3016-3020. [CrossRef] [PubMed]

75. Vidal-Dupiol, J.; Ladrière, O.; Meistertzheim, A.L.; Fouré, L.; Adjeroud, M.; Mitta, G. Physiological responses of the scleractinian coral Pocillopora damicornis to bacterial stress from Vibrio coralliilyticus. J. Exp. Biol. 2011, 214, 1533-1545. [CrossRef]

76. Palincsar, E.E.; Jones, W.R.; Palincsar, J.S.; Glogowski, M.A.; Mastro, J.L. Bacterial aggregates within the epidermis of the sea anemone Aiptasia pallida. Biol. Bull. 1989, 177, 130-140. [CrossRef]

77. Kremer, N.; Philipp, E.E.R.; Carpentier, M.-C.; Brennan, C.A.; Kraemer, L.; Altura, M.A.; Augustin, R.; Häsler, R.; Heath-Heckman, E.A.C.; Peyer, S.M.; et al. Initial symbiont contact orchestrates host-organ-wide transcriptional changes that prime tissue colonization. Cell Host Microbe 2013, 14, 183-194. [CrossRef] [PubMed]

78. McFall-Ngai, M.J.; Ruby, E.G. Symbiont recognition and subsequent morphogenesis as early events in an animal-bacterial mutualism. Science 1991, 254, 1491-1494. [CrossRef]

79. Tandon, K.; Lu, C.-Y.; Chiang, P.-W.; Wada, N.; Yang, S.-H.; Chan, Y.-F.; Chen, P.-Y.; Chang, H.-Y.; Chiou, Y.-J.; Chou, M.-S.; et al. Comparative genomics: Dominant coral-bacterium Endozoicomonas acroporae metabolizes dimethylsulfoniopropionate (DMSP). ISME J. 2020, 14, 1290-1303. [CrossRef] [PubMed]

80. Bell, W.; Mitchell, R. Chemotactic and growth responses of marine bacteria to algal extracellular products. Biol. Bull. 1972, 143, 265-277. [CrossRef]

81. Seymour, J.R.; Amin, S.A.; Raina, J.B.; Stocker, R. Zooming in on the phycosphere: The ecological interface for phytoplanktonbacteria relationships. Nat. Microbiol. 2017, 2, 17065. [CrossRef]

82. Garrido, A.G.; Machado, L.F.; Zilberberg, C.; Leite, D.C. de A. Insights into 'Symbiodiniaceae phycosphere' in a coral holobiont. Symbiosis 2021, 83, 25-39. [CrossRef]

83. Motone, K.; Takagi, T.; Aburaya, S.; Miura, N.; Aoki, W.; Ueda, M. A Zeaxanthin-producing bacterium isolated from the algal phycosphere protects coral endosymbionts from environmental stress. MBio 2020, 11, e01019-19. [CrossRef]

84. Matthews, J.L.; Raina, J.; Kahlke, T.; Seymour, J.R.; van Oppen, M.J.H.; Suggett, D.J. Symbiodiniaceae-bacteria interactions: Rethinking metabolite exchange in reef-building corals as multi-partner metabolic networks. Environ. Microbiol. 2020, $22,1675$. [CrossRef]

85. Camp, E.F.; Kahlke, T.; Nitschke, M.R.; Varkey, D.; Fisher, N.L.; Fujise, L.; Goyen, S.; Hughes, D.J.; Lawson, C.A.; Ros, M.; et al. Revealing changes in the microbiome of Symbiodiniaceae under thermal stress. Environ. Microbiol. 2020, 22, 1294-1309. [CrossRef] [PubMed]

86. Lawson, C.A.; Raina, J.-B.; Kahlke, T.; Seymour, J.R.; Suggett, D.J. Defining the core microbiome of the symbiotic dinoflagellate, Symbiodinium. Environ. Microbiol. Rep. 2018, 10,7-11. [CrossRef] [PubMed]

87. Amin, S.A.; Parker, M.S.; Armbrust, E.V. Interactions between diatoms and bacteria. Microbiol. Mol. Biol. Rev. 2012, 76, 667-684. [CrossRef] [PubMed]

88. Ramanan, R.; Kim, B.-H.; Cho, D.-H.; Oh, H.-M.; Kim, H.-S. Algae-bacteria interactions: Evolution, ecology and emerging applications. Biotechnol. Adv. 2016, 34, 14-29. [CrossRef] [PubMed]

89. Grant, M.A.A.; Kazamia, E.; Cicuta, P.; Smith, A.G. Direct exchange of vitamin B12 is demonstrated by modelling the growth dynamics of algal-bacterial cocultures. ISME J. 2014, 8, 1418-1427. [CrossRef] [PubMed]

90. Xie, B.; Bishop, S.; Stessman, D.; Wright, D.; Spalding, M.H.; Halverson, L.J. Chlamydomonas reinhardtii thermal tolerance enhancement mediated by a mutualistic interaction with vitamin B12-producing bacteria. ISME J. 2013, 7, 1544-1555. [CrossRef] [PubMed] 
91. Croft, M.T.; Lawrence, A.D.; Raux-Deery, E.; Warren, M.J.; Smith, A.G. Algae acquire vitamin B12 through a symbiotic relationship with bacteria. Nature 2005, 438, 90-93. [CrossRef]

92. Amin, S.A.; Green, D.H.; Hart, M.C.; Küpper, F.C.; Sunda, W.G.; Carrano, C.J. Photolysis of iron-siderophore chelates promotes bacterial-algal mutualism. Proc. Natl. Acad. Sci. USA 2009, 106, 17071-17076. [CrossRef]

93. Amin, S.A.; Hmelo, L.R.; Van Tol, H.M.; Durham, B.P.; Carlson, L.T.; Heal, K.R.; Morales, R.L.; Berthiaume, C.T.; Parker, M.S.; Djunaedi, B.; et al. Interaction and signalling between a cosmopolitan phytoplankton and associated bacteria. Nature 2015, 522, 98-101. [CrossRef]

94. Schulz, F.; Horn, M. Intranuclear bacteria: Inside the cellular control center of eukaryotes. Trends Cell Biol. 2015, 25, 339-346. [CrossRef]

95. Córdova, J.L.; Escudero, C.; Bustamante, J. Bloom inside the bloom: Intracellular bacteria multiplication within toxic dinoflagellates. Rev. Biol. Mar. Oceanogr. 2003, 38, 57-67. [CrossRef]

96. Kirchner, M.; Sahling, G.; Schütt, C.; Döpke, H.; Uhlig, G. Intracellular bacteria in the red tide-forming heterotrophic dinoflagellate Noctiluca scintillans. Arch. Hydrobiol. Spec. Issue Adv. Limnol 1999, 54, 297.

97. Biegala, I.C.; Kennaway, G.; Alverca, E.; Lennon, J.; Vaulot, D.; Simon, N. Identification of bacteria associated with dinoflagellates (Dinophyceae) Alexandrium spp. using tyramide signal amplification-fluorescent in situ hybridization and confocal microscopy. J. Phycol. 2002, 38, 404-411. [CrossRef]

98. Bird, C.; Darling, K.F.; Russell, A.D.; Davis, C.V.; Fehrenbacher, J.; Free, A.; Wyman, M.; Ngwenya, B.T. Cyanobacterial endobionts within a major marine planktonic calcifier (Globigerina bulloides, Foraminifera) revealed by $16 \mathrm{~S}$ rRNA metabarcoding. Biogeosciences 2017, 14, 901-920. [CrossRef]

99. Raina, J.B.; Clode, P.L.; Cheong, S.; Bougoure, J.; Kilburn, M.R.; Reeder, A.; Forêt, S.; Stat, M.; Beltran, V.; Thomas-Hall, P.; et al. Subcellular tracking reveals the location of dimethylsulfoniopropionate in microalgae and visualises its uptake by marine bacteria. Elife 2017, 6, e23008. [CrossRef] [PubMed]

100. Gao, C.; Fernandez, V.I.; Lee, K.S.; Fenizia, S.; Pohnert, G.; Seymour, J.R.; Raina, J.-B.; Stocker, R. Single-cell bacterial transcription measurements reveal the importance of dimethylsulfoniopropionate (DMSP) hotspots in ocean sulfur cycling. Nat. Commun. 2020, 11, 1942. [CrossRef] [PubMed]

101. Sunda, W.; Kieber, D.J.; Kiene, R.P.; Huntsman, S. An antioxidant function for DMSP and DMS in marine algae. Nature 2002, 418, 317-320. [CrossRef] [PubMed]

102. Ceh, J.; Kilburn, M.R.; Cliff, J.B.; Raina, J.-B.; van Keulen, M.; Bourne, D.G. Nutrient cycling in early coral life stages: Pocillopora damicornis larvae provide their algal symbiont (Symbiodinium) with nitrogen acquired from bacterial associates. Ecol. Evol. 2013, 3, 2393-2400. [CrossRef]

103. Harrison, P.L. Sexual reproduction of scleractinian corals. In Coral Reefs: An Ecosystem in Transition; Springer: Dordrecht, The Netherlands, 2011; pp. 59-85. ISBN 9789400701137.

104. Shikina, S.; Ching-FongChang, C.F. Sexual reproduction in stony corals and insight into the evolution of oogenesis in cnidaria. In The Cnidaria, Past, Present and Future: The World of Medusa and Her Sisters; Springer International Publishing: Berlin/Heidelberg, Germany, 2016; pp. 249-268. ISBN 9783319313054.

105. Kupper, M.; Stigloher, C.; Feldhaar, H.; Gross, R. Distribution of the obligate endosymbiont Blochmannia floridanus and expression analysis of putative immune genes in ovaries of the carpenter ant Camponotus floridanus. Arthropod Struct. Dev. 2016, 45, 475-487. [CrossRef]

106. Luan, J.-B.; Shan, H.-W.; Isermann, P.; Huang, J.-H.; Lammerding, J.; Liu, S.-S.; Douglas, A.E. Cellular and molecular remodelling of a host cell for vertical transmission of bacterial symbionts. Proc. Biol. Sci. 2016, 283, 218-230. [CrossRef] [PubMed]

107. Salem, H.; Bauer, E.; Kirsch, R.; Berasategui, A.; Cripps, M.; Weiss, B.; Koga, R.; Fukumori, K.; Vogel, H.; Fukatsu, T.; et al. Drastic genome reduction in an herbivore's pectinolytic symbiont. Cell 2017, 171, 1520-1531. [CrossRef]

108. Maire, J.; Chouaia, B.; Zaidman-Rémy, A.; Heddi, A. Endosymbiosis morphological reorganization during metamorphosis diverges in weevils. Commun. Integr. Biol. 2020, 13, 184-188. [CrossRef]

109. Watanabe, K.; Yukuhiro, F.; Matsuura, Y.; Fukatsu, T.; Noda, H. Intrasperm vertical symbiont transmission. Proc. Natl. Acad. Sci. USA 2014, 111, 7433-7437. [CrossRef]

110. Salem, H.; Florez, L.; Gerardo, N.; Kaltenpoth, M. An out-of-body experience: The extracellular dimension for the transmission of mutualistic bacteria in insects. Proc. R. Soc. B Biol. Sci. 2015, 282, 20142957. [CrossRef] [PubMed]

111. Damjanovic, K.; Menéndez, P.; Blackall, L.L.; van Oppen, M.J.H. Early life stages of a common broadcast spawning coral associate with specific bacterial communities despite lack of internalized bacteria. Microb. Ecol. 2019, 79, 706-719. [CrossRef]

112. Bernasconi, R.; Stat, M.; Koenders, A.; Paparini, A.; Bunce, M.; Huggett, M.J. Establishment of coral-bacteria symbioses reveal changes in the core bacterial community with host ontogeny. Front. Microbiol. 2019, 10, 1529. [CrossRef]

113. Leite, D.C.A.; Leão, P.; Garrido, A.G.; Lins, U.; Santos, H.F.; Pires, D.O.; Castro, C.B.; van Elsas, J.D.; Zilberberg, C.; Rosado, A.S.; et al. Broadcast spawning coral Mussismilia hispida can vertically transfer its associated bacterial core. Front. Microbiol. 2017, 8 , 176. [CrossRef]

114. Johansson, M.E.V.; Hansson, G.C. Preservation of mucus in histological sections, immunostaining of mucins in fixed tissue, and localization of bacteria with FISH. Methods Mol. Biol. 2012, 842, 229-235. [CrossRef] [PubMed]

115. Attardo, G.M.; Lohs, C.; Heddi, A.; Alam, U.H.; Yildirim, S.; Aksoy, S. Analysis of milk gland structure and function in Glossina morsitans: Milk protein production, symbiont populations and fecundity. J. Insect Physiol. 2008, 54, 1236-1242. [CrossRef] 
116. Collingro, A.; Köstlbacher, S.; Horn, M. Chlamydiae in the environment. Trends Microbiol. 2020, 28, 877. [CrossRef] [PubMed]

117. Sharma, R.; Lahiri, R.; Scollard, D.M.; Pena, M.; Williams, D.L.; Adams, L.B.; Figarola, J.; Truman, R.W. The armadillo: A model for the neuropathy of leprosy and potentially other neurodegenerative diseases. DMM Dis. Model. Mech. 2013, 6, 19-24. [CrossRef] [PubMed]

118. Huggett, M.J.; Apprill, A. Coral microbiome database: Integration of sequences reveals high diversity and relatedness of coral-associated microbes. Environ. Microbiol. Rep. 2019, 11, 372-385. [CrossRef]

119. Shaver, E.C.; Shantz, A.A.; McMinds, R.; Burkepile, D.E.; Thurber, R.L.V.; Silliman, B.R. Effects of predation and nutrient enrichment on the success and microbiome of a foundational coral. Ecology 2017, 98, 830-839. [CrossRef]

120. Klinges, G.; Maher, R.L.; Thurber, R.L.V.; Muller, E.M. Parasitic 'Candidatus Aquarickettsia rohweri' is a marker of disease susceptibility in Acropora cervicornis but is lost during thermal stress. Environ. Microbiol. 2020, 22, 5341. [CrossRef] [PubMed]

121. Baker, L.J.; Reich, H.G.; Kitchen, S.A.; Grace Klinges, J.; Koch, H.R.; Baums, I.B.; Muller, E.M.; Thurber, R.V. The coral symbiont Candidatus Aquarickettsia is variably abundant in threatened Caribbean acroporids and transmitted horizontally. ISME J. 2021, 1-12. [CrossRef]

122. Kaufmann, S.H.E. Intracellular pathogens: Living in an extreme environment. Immunol. Rev. 2011, 240, 5-10. [CrossRef] [PubMed]

123. Chan, W.Y.; Peplow, L.M.; Menéndez, P.; Hoffmann, A.A.; van Oppen, M.J.H. The roles of age, parentage and environment on bacterial and algal endosymbiont communities in Acropora corals. Mol. Ecol. 2019, 28, 3830. [CrossRef] [PubMed]

124. Ziegler, M.; Grupstra, C.G.B.; Barreto, M.M.; Eaton, M.; BaOmar, J.; Zubier, K.; Al-Sofyani, A.; Turki, A.J.; Ormond, R.; Voolstra, C.R. Coral bacterial community structure responds to environmental change in a host-specific manner. Nat. Commun. 2019, 10, 3092. [CrossRef] [PubMed]

125. Damjanovic, K.; Blackall, L.L.; Peplow, L.M.; van Oppen, M.J.H. Assessment of bacterial community composition within and among Acropora loripes colonies in the wild and in captivity. Coral Reefs 2020, 39, 1245. [CrossRef]

126. Moran, N.A.; Bennett, G.M. The tiniest tiny genomes. Annu. Rev. Microbiol. 2014, 68, 195-215. [CrossRef]

127. Hernandez-Agreda, A.; Gates, R.D.; Ainsworth, T.D. Defining the core microbiome in corals' microbial soup. Trends Microbiol. 2017, 25, 125-140. [CrossRef]

128. Bennett, G.M.; Moran, N.A. Small, smaller, smallest: The origins and evolution of ancient dual symbioses in a Phloem-feeding insect. Genome Biol. Evol. 2013, 5, 1675-1688. [CrossRef] [PubMed]

129. Moran, N.A. Accelerated evolution and Muller's rachet in endosymbiotic bacteria. Proc. Natl. Acad. Sci. USA 1996, 93, 2873-2878. [CrossRef]

130. Dale, C.; Wang, B.; Moran, N.; Ochman, H. Loss of DNA recombinational repair enzymes in the initial stages of genome degeneration. Mol. Biol. Evol. 2003, 20, 1188-1194. [CrossRef] [PubMed]

131. Clayton, A.L.; Jackson, D.G.; Weiss, R.B.; Dale, C. Adaptation by deletogenic replication slippage in a nascent symbiont. Mol. Biol. Evol. 2016, 33, 1957-1966. [CrossRef] [PubMed]

132. Moran, N.A.; McCutcheon, J.P.; Nakabachi, A. Genomics and evolution of heritable bacterial symbionts. Annu. Rev. Genet. 2008, 42, 165-190. [CrossRef] [PubMed]

133. Moya, A.; Peretó, J.; Gil, R.; Latorre, A. Learning how to live together: Genomic insights into prokaryote-animal symbioses. Nat. Rev. Genet. 2008, 9, 218-229. [CrossRef] [PubMed]

134. Blattner, F.R.; Plunkett, G.; Bloch, C.A.; Perna, N.T.; Burland, V.; Riley, M.; Collado-Vides, J.; Glasner, J.D.; Rode, C.K.; Mayhew, G.F.; et al. The complete genome sequence of Escherichia coli K-12. Science 1997, 277, 1453-1462. [CrossRef]

135. Haygood, M.G.; Tebo, B.M.; Nealson, K.H. Luminous bacteria of a monocentrid fish (Monocentris japonicus) and two anomalopid fishes (Photoblepharon palpebratus and Kryptophanaron alfredi): Population sizes and growth within the light organs, and rates of release into the seawater. Mar. Biol. 1984, 78, 249-254. [CrossRef]

136. Hendry, T.A.; de Wet, J.R.; Dougan, K.E.; Dunlap, P.V. Genome evolution in the obligate but environmentally active luminous symbionts of flashlight fish. Genome Biol. Evol. 2016, 8, 2203-2213. [CrossRef]

137. Anbutsu, H.; Moriyama, M.; Nikoh, N.; Hosokawa, T.; Futahashi, R.; Tanahashi, M.; Meng, X.-Y.; Kuriwada, T.; Mori, N.; Oshima, K.; et al. Small genome symbiont underlies cuticle hardness in beetles. Proc. Natl. Acad. Sci. USA 2017, 114, E8382-E8391. [CrossRef]

138. Sheik, C.S.; Reese, B.K.; Twing, K.I.; Sylvan, J.B.; Grim, S.L.; Schrenk, M.O.; Sogin, M.L.; Colwell, F.S. Identification and removal of contaminant sequences from ribosomal gene databases: Lessons from the Census of Deep Life. Front. Microbiol. $2018,9,840$. [CrossRef]

139. Salter, S.J.; Cox, M.J.; Turek, E.M.; Calus, S.T.; Cookson, W.O.; Moffatt, M.F.; Turner, P.; Parkhill, J.; Loman, N.J.; Walker, A.W. Reagent and laboratory contamination can critically impact sequence-based microbiome analyses. BMC Biol. $2014,12,87$. [CrossRef] [PubMed]

140. Degnan, P.H.; Lazarus, A.B.; Brock, C.D.; Wernegreen, J.J. Host-symbiont stability and fast evolutionary rates in an ant-bacterium association: Cospeciation of Camponotus species and their endosymbionts, Candidatus blochmannia. Syst. Biol. 2004, 53, 95-110. [CrossRef] [PubMed]

141. Munson, M.A.; Baumann, P.; Morant, N.A. Phylogenetic relationships of the endosymbionts of mealybugs (Homoptera: Pseudococcidae) based on 165 rDNA sequences. Mol. Phylogenet. Evol. 1992, 1, 26-30. [CrossRef]

142. Pollock, F.J.; McMinds, R.; Smith, S.; Bourne, D.G.; Willis, B.L.; Medina, M.; Thurber, R.V.; Zaneveld, J.R. Coral-associated bacteria demonstrate phylosymbiosis and cophylogeny. Nat. Commun. 2018, 9, 4921. [CrossRef] 
143. O’Brien, P.A.; Tan, S.; Yang, C.; Frade, P.R.; Andreakis, N.; Smith, H.A.; Miller, D.J.; Webster, N.S.; Zhang, G.; Bourne, D.G. Diverse coral reef invertebrates exhibit patterns of phylosymbiosis. ISME J. 2020, 14, 2211. [CrossRef] [PubMed]

144. O'Brien, P.A.; Andreakis, N.; Tan, S.; Miller, D.J.; Webster, N.S.; Zhang, G.; Bourne, D.G. Testing Cophylogeny between Coral Reef Invertebrates and Their Bacterial and Archaeal Symbionts. Molecular Ecology 2021, 30, 3768. [CrossRef] [PubMed]

145. Ritchie, K.B. Regulation of microbial populations by coral surface mucus and mucus-associated bacteria. Mar. Ecol. Prog. Ser. 2006, 322, 1-14. [CrossRef]

146. Thompson, J.R.; Rivera, H.E.; Closek, C.J.; Medina, M. Microbes in the coral holobiont: Partners through evolution, development, and ecological interactions. Front. Cell. Infect. Microbiol. 2014, 4, 176. [CrossRef]

147. Lema, K.A.; Clode, P.L.; Kilburn, M.R.; Thornton, R.; Willis, B.L.; Bourne, D.G. Imaging the uptake of nitrogen-fixing bacteria into larvae of the coral Acropora millepora. ISME J. 2016, 10, 1804-1808. [CrossRef]

148. Lesser, M.; Falcón, L.; Rodríguez-Román, A.; Enríquez, S.; Hoegh-Guldberg, O.; Iglesias-Prieto, R. Nitrogen fixation by symbiotic cyanobacteria provides a source of nitrogen for the scleractinian coral Montastraea cavernosa. Mar. Ecol. Prog. Ser. 2007, 346, 143-152. [CrossRef]

149. Duron, O.; Morel, O.; Noël, V.; Buysse, M.; Binetruy, F.; Lancelot, R.; Loire, E.; Ménard, C.; Bouchez, O.; Vavre, F.; et al. Tick-Bacteria mutualism depends on B vitamin synthesis pathways. Curr. Biol. 2018, 28, 1896-1902. [CrossRef] [PubMed]

150. Bent, S.M.; Miller, C.A.; Sharp, K.H.; Hansel, C.M.; Apprill, A. Differential Patterns of Microbiota Recovery in Symbiotic and Aposymbiotic Corals following Antibiotic Disturbance. mSystems 2021, 6, e01086-20. [CrossRef] [PubMed]

151. Shigenobu, S.; Watanabe, H.; Hattori, M.; Sakaki, Y.; Ishikawa, H. Genome sequence of the endocellular bacterial symbiont of aphids Buchnera sp. APS. Nature 2000, 407, 81-86. [CrossRef]

152. McCutcheon, J.P.; Moran, N.A. Extreme genome reduction in symbiotic bacteria. Nat. Rev. Microbiol. 2012, 10, 13-26. [CrossRef]

153. Bing, X.; Attardo, G.M.; Vigneron, A.; Aksoy, E.; Scolari, F.; Malacrida, A.; Weiss, B.L.; Aksoy, S. Unravelling the relationship between the tsetse fly and its obligate symbiont Wigglesworthia: Transcriptomic and metabolomic landscapes reveal highly integrated physiological networks. Proc. Biol. Sci. 2017, 284, 20170360. [CrossRef] [PubMed]

154. Grote, A.; Voronin, D.; Ding, T.; Twaddle, A.; Unnasch, T.R.; Lustigman, S.; Ghedin, E. Defining Brugia malayi and Wolbachia symbiosis by stage-specific dual RNA-seq. PLoS Negl. Trop. Dis. 2017, 11, e0005357. [CrossRef] [PubMed]

155. Medina Munoz, M.; Pollio, A.R.; White, H.L.; Rio, R.V.M. Into the wild: Parallel transcriptomics of the tsetse-Wigglesworthia mutualism within kenyan populations. Genome Biol. Evol. 2017, 9, 2276-2291. [CrossRef]

156. Maire, J.; Parisot, N.; Galvao Ferrarini, M.; Vallier, A.; Gillet, B.; Hughes, S.; Balmand, S.; Vincent-Monégat, C.; Zaidman-Rémy, A.; Heddi, A. Spatial and morphological reorganization of endosymbiosis during metamorphosis accommodates adult metabolic requirements in a weevil. Proc. Natl. Acad. Sci. USA 2020, 117, 19347-19358. [CrossRef]

157. Buerger, P.; Alvarez-Roa, C.; Coppin, C.W.; Pearce, S.L.; Chakravarti, L.J.; Oakeshott, J.G.; Edwards, O.R.; van Oppen, M.J.H. Heat-evolved microalgal symbionts increase coral bleaching tolerance. Sci. Adv. 2020, 6, eaba2498. [CrossRef]

158. Sweet, M.; Villela, H.; Keller-Costa, T.; Costa, R.; Romano, S.; Bourne, D.G.; Cárdenas, A.; Huggett, M.J.; Kerwin, A.H.; Kuek, F.; et al. Insights into the Cultured Bacterial Fraction of Corals. mSystems 2021, 6, e0124920. [CrossRef]

159. Masson, F.; Calderon Copete, S.; Schüpfer, F.; Garcia-Arraez, G.; Lemaitre, B. In vitro culture of the insect endosymbiont Spiroplasma poulsonii highlights bacterial genes involved in host-symbiont interaction. MBio 2018, 9, e00024-18. [CrossRef]

160. Dale, C.; Maudlin, I. Sodalis gen. nov. and Sodalis glossinidius sp. nov., a microaerophilic secondary endosymbiont of the tsetse fly Glossina morsitans morsitans. Int. J. Syst. Bacteriol. 1999, 49, 267-275. [CrossRef]

161. Dale, C.; Beeton, M.; Harbison, C.; Jones, T.; Pontes, M. Isolation, pure culture, and characterization of "Candidatus arsenophonus arthropodicus," an intracellular secondary endosymbiont from the hippoboscid louse fly Pseudolynchia canariensis. Appl. Environ. Microbiol. 2006, 72, 2997-3004. [CrossRef]

162. Brandt, J.W.; Chevignon, G.; Oliver, K.M.; Strand, M.R. Culture of an aphid heritable symbiont demonstrates its direct role in defence against parasitoids. Proc. R. Soc. B Biol. Sci. 2017, 284, 20171925. [CrossRef]

163. Sabri, A.; Leroy, P.; Haubruge, E.; Hance, T.; Frère, I.; Destain, J.; Thonart, P. Isolation, pure culture and characterization of serratia symbiotica sp. nov., the R-type of Secondary endosymbiont of the black bean aphid Aphis fabae. Int. J. Syst. Evol. Microbiol. 2011, 61, 2081-2088. [CrossRef]

164. Zaidman-Rémy, A.; Vigneron, A.; Weiss, B.L.; Heddi, A. What can a weevil teach a fly, and reciprocally? Interaction of host immune systems with endosymbionts in Glossina and Sitophilus. BMC Microbiol. 2018, 18, 150. [CrossRef] [PubMed]

165. Certner, R.H.; Vollmer, S.V. Evidence for Autoinduction and Quorum Sensing in White Band Disease-Causing Microbes on Acropora cervicornis. Sci. Rep. 2015, 5, 11134. [CrossRef] [PubMed]

166. Rosental, B.; Kozhekbaeva, Z.; Fernhoff, N.; Tsai, J.M.; Traylor-Knowles, N. Coral cell separation and isolation by fluorescenceactivated cell sorting (FACS). BMC Cell Biol. 2017, 18, 30. [CrossRef] [PubMed]

167. van Oppen, M.J.H.; Oliver, J.K.; Putnam, H.M.; Gates, R.D. Building coral reef resilience through assisted evolution. Proc. Natl. Acad. Sci. USA 2015, 112, 2307-2313. [CrossRef] [PubMed]

168. Peixoto, R.S.; Rosado, P.M.; Leite, D.C.D.A.; Rosado, A.S.; Bourne, D.G. Beneficial Microorganisms for Corals (BMC): Proposed mechanisms for coral health and resilience. Front. Microbiol. 2017, 8, 341. [CrossRef]

169. Van Oppen, M.J.H.; Gates, R.D.; Blackall, L.L.; Cantin, N.; Chakravarti, L.J.; Chan, W.Y.; Cormick, C.; Crean, A.; Damjanovic, K.; Epstein, H.; et al. Shifting paradigms in restoration of the world's coral reefs. Glob. Chang. Biol. 2017, 23, 3437-3448. [CrossRef]

170. Blackall, L.L.; Dungan, A.M.; Hartman, L.M.; van Oppen, M.J. Probiotics for corals. Microbiol. Aust. 2020, 41, 100-104. [CrossRef] 
171. Dungan, A.M.; Bulach, D.; Lin, H.; van Oppen, M.J.H.; Blackall, L.L. Development of a free radical scavenging bacterial consortium to mitigate oxidative stress in cnidarians. Microb. Biotechnol. 2021, 14, 2025-2040. [CrossRef]

172. Damjanovic, K.; van Oppen, M.J.H.; Menéndez, P.; Blackall, L.L. Experimental inoculation of coral recruits with marine bacteria indicates scope for microbiome manipulation in Acropora tenuis and Platygyra daedalea. Front. Microbiol. 2019, 10, 1702. [CrossRef]

173. Damjanovic, K.; Blackall, L.L.; Webster, N.S.; van Oppen, M.J.H. The contribution of microbial biotechnology to mitigating coral reef degradation. Microb. Biotechnol. 2017, 10, 1236-1243. [CrossRef] [PubMed]

174. Rosado, P.M.; Leite, D.C.A.; Duarte, G.A.S.; Chaloub, R.M.; Jospin, G.; Nunes da Rocha, U.; Saraiva, J.P.; Dini-Andreote, F.; Eisen, J.A.; Bourne, D.G.; et al. Marine probiotics: Increasing coral resistance to bleaching through microbiome manipulation. ISME J. 2019, 13, 921-936. [CrossRef]

175. Doering, T.; Wall, M.; Putchim, L.; Rattanawongwan, T.; Schroeder, R.; Hentschel, U.; Roik, A. Towards enhancing coral heat tolerance: A "microbiome transplantation" treatment using inoculations of homogenized coral tissues. Microbiome 2021, 9, 102. [CrossRef]

176. Santoro, E.P.; Borges, R.M.; Espinoza, J.L.; Freire, M.; Messias, C.S.M.A.; Villela, H.D.M.; Pereira, L.M.; Vilela, C.L.S.; Rosado, J.G.; Cardoso, P.M.; et al. Coral microbiome manipulation elicits metabolic and genetic restructuring to mitigate heat stress and evade mortality. Sci. Adv. 2021, 7, eabg3088. [CrossRef] [PubMed]

177. Flores, H.A.; O’Neill, S.L. Controlling vector-borne diseases by releasing modified mosquitoes. Nat. Rev. Microbiol. 2018, 16, 508-518. [CrossRef] [PubMed]

178. Hilgenboecker, K.; Hammerstein, P.; Schlattmann, P.; Telschow, A.; Werren, J.H. How many species are infected with Wolbachia?A statistical analysis of current data. FEMS Microbiol. Lett. 2008, 281, 215-220. [CrossRef] [PubMed]

179. Zug, R.; Hammerstein, P. Still a host of hosts for Wolbachia: Analysis of recent data suggests that $40 \%$ of terrestrial arthropod species are infected. PLoS ONE 2012, 7, e38544. [CrossRef]

180. Werren, J.H.; Baldo, L.; Clark, M.E. Wolbachia: Master manipulators of invertebrate biology. Nat. Rev. Microbiol. $2008,6,741-751$. [CrossRef] [PubMed]

181. Teixeira, L.; Ferreira, A.; Ashburner, M. The bacterial symbiont Wolbachia induces resistance to RNA viral infections in Drosophila melanogaster. PLoS Biol. 2008, 6, e2. [CrossRef] [PubMed]

182. Moreira, L.A.; Iturbe-Ormaetxe, I.; Jeffery, J.A.; Lu, G.; Pyke, A.T.; Hedges, L.M.; Rocha, B.C.; Hall-Mendelin, S.; Day, A.; Riegler, M.; et al. A Wolbachia symbiont in Aedes aegypti limits infection with dengue, Chikungunya, and Plasmodium. Cell 2009, 139, 1268-1278. [CrossRef]

183. Dutra, H.L.C.; Rocha, M.N.; Dias, F.B.S.; Mansur, S.B.; Caragata, E.P.; Moreira, L.A. Wolbachia blocks currently circulating Zika virus isolates in brazilian Aedes aegypti mosquitoes. Cell Host Microbe 2016, 19, 771-774. [CrossRef]

184. Walker, T.; Johnson, P.H.; Moreira, L.A.; Iturbe-Ormaetxe, I.; Frentiu, F.D.; McMeniman, C.J.; Leong, Y.S.; Dong, Y.; Axford, J.; Kriesner, P.; et al. The wMel Wolbachia strain blocks dengue and invades caged Aedes aegypti populations. Nature 2011, 476, 450-455. [CrossRef]

185. McMeniman, C.J.; Lane, R.V.; Cass, B.N.; Fong, A.W.C.; Sidhu, M.; Wang, Y.-F.; O'Neill, S.L. Stable introduction of a life-shortening Wolbachia infection into the mosquito Aedes aegypti. Science 2009, 323, 141-144. [CrossRef]

186. Hoffmann, A.A.; Iturbe-Ormaetxe, I.; Callahan, A.G.; Phillips, B.L.; Billington, K.; Axford, J.K.; Montgomery, B.; Turley, A.P.; O'Neill, S.L. Stability of the wMel Wolbachia infection following invasion into Aedes aegypti populations. PLoS Negl. Trop. Dis. 2014, 8, e3115. [CrossRef]

187. Frentiu, F.D.; Zakir, T.; Walker, T.; Popovici, J.; Pyke, A.T.; van den Hurk, A.; McGraw, E.A.; O’Neill, S.L. Limited Dengue virus replication in field-collected Aedes aegypti mosquitoes infected with Wolbachia. PLoS Negl. Trop. Dis. 2014, 8, e2688. [CrossRef]

188. Ryan, P.A.; Turley, A.P.; Wilson, G.; Hurst, T.P.; Retzki, K.; Brown-Kenyon, J.; Hodgson, L.; Kenny, N.; Cook, H.; Montgomery, B.L.; et al. Establishment of wMel Wolbachia in Aedes aegypti mosquitoes and reduction of local dengue transmission in Cairns and surrounding locations in northern Queensland, Australia. Gates Open Res. 2020, 3, 1547. [CrossRef]

189. Popovici, J.; Moreira, L.A.; Poinsignon, A.; Iturbe-Ormaetxe, I.; McNaughton, D.; O’Neill, S.L. Assessing key safety concerns of a Wolbachia-based strategy to control dengue transmission by Aedes mosquitoes. Mem. Inst. Oswaldo Cruz 2010, 105, 957-964. [CrossRef]

190. Masson, F.; Schüpfer, F.; Jollivet, C.; Lemaitre, B. Transformation of the Drosophila sex-manipulative endosymbiont Spiroplasma poulsonii and persisting hurdles for functional genetics studies. Appl. Environ. Microbiol. 2020, 86, e00835-20. [CrossRef] [PubMed]

191. Durvasula, R.V.; Gumbs, A.; Panackal, A.; Kruglov, O.; Aksoy, S.; Merrifield, R.B.; Richards, F.F.; Beard, C.B. Prevention of insect-borne disease: An approach using transgenic symbiotic bacteria. Proc. Natl. Acad. Sci. USA 1997, 94, 3274-3278. [CrossRef] [PubMed]

192. Durvasula, R.V.; Sundaram, R.K.; Kirsch, P.; Hurwitz, I.; Crawford, C.V.; Dotson, E.; Beard, C.B. Genetic transformation of a Corynebacterial symbiont from the Chagas disease vector Triatoma infestans. Exp. Parasitol. 2008, 119, 94-98. [CrossRef] [PubMed]

193. Chakravarti, L.J.; Beltran, V.H.; van Oppen, M.J.H. Rapid thermal adaptation in photosymbionts of reef-building corals. Glob. Chang. Biol. 2017, 23, 4675-4688. [CrossRef] [PubMed] 